\title{
Ecohydrological travel times derived from in situ stable water isotope measurements in trees during a semi-controlled pot experiment
}

\author{
David Mennekes $^{1, a}$, Michael Rinderer ${ }^{1}$, Stefan Seeger ${ }^{1}$, and Natalie Orlowski ${ }^{1}$ \\ ${ }^{1}$ Hydrology, University of Freiburg, Freiburg im Breisgau, Germany \\ anow at: Empa - Swiss Federal Laboratories for Materials Science and Technology, \\ Technology and Society Laboratory, St. Gallen, Switzerland
}

Correspondence: David Mennekes (david.mennekes@posteo.de)

Received: 22 December 2020 - Discussion started: 9 February 2021

Revised: 10 May 2021 - Accepted: 16 July 2021 - Published: 23 August 2021

\begin{abstract}
Tree water uptake processes and ecohydrological travel times have gained more attention in recent ecohydrological studies. In situ measurement techniques for stable water isotopes offer great potential to investigate these processes but have not been applied much to tree xylem and soils so far. Here, we used in situ probes for stable water isotope measurements to monitor the isotopic signatures of soil and tree xylem water before and after two deuteriumlabeled irrigation experiments. To show the potential of the method, we tested our measurement approach with 20-yearold trees of three different species (Pinus pinea, Alnus incana and Quercus suber). They were planted in large pots with homogeneous soil in order to have semi-controlled experimental conditions. Additional destructive sampling of soil and plant material allowed for a comparison between destructive (cryogenic vacuum extraction and direct water vapor equilibration) and in situ isotope measurements. Furthermore, isotope-tracer-based ecohydrological travel times were compared to travel times derived from sap flow measurements. The time to first arrival of the isotope tracer signals at $15 \mathrm{~cm}$ stem hight were ca. $17 \mathrm{~h}$ for all tree species and matched well with sap-flow-based travel times. However, at $150 \mathrm{~cm}$ stem height tracer-based travel times differed between tree species and ranged between 2.4 and $3.3 \mathrm{~d}$. Sap-flow-based travel times at $150 \mathrm{~cm}$ stem hight were ca. $1.3 \mathrm{~d}$ longer than tracer-based travel times. The isotope signature of destructive and in situ isotope measurements differed notably, which suggests that the two types of techniques sampled water from different pools. In situ measurements of soil and xylem wa-
\end{abstract}

ter were much more consistent between the three tree pots (on average standard deviations were smaller by $8.4 \%$ for $\delta^{2} \mathrm{H}$ and by $1.6 \%$ for $\delta^{18} \mathrm{O}$ for the in situ measurements) and also among the measurements from the same tree pot in comparison to the destructive methods (on average standard deviations were smaller by $7.8 \%$ and $1.6 \%$ for $\delta^{2} \mathrm{H}$ and $\delta^{18} \mathrm{O}$, respectively). Our study demonstrates the potential of semi-controlled large-scale pot experiments and very frequent in situ isotope measurements for monitoring tree water uptake and ecohydrological travel times. It also shows that differences in sampling techniques or sensor types need to be considered when comparing results of different studies and within one study using different methods.

\section{Introduction}

Rapid and small-scale processes driving interactions in the soil-plant-atmosphere system have only recently gained attention and are, so far, neglected in most ecohydrological models. Challenges are partly the lack of sufficiently resolved data but also the lack of ecohydrological process understanding, e.g., the origin of water used by different tree species (Brinkmann et al., 2018; Ellsworth et al., 2007; Sprenger et al., 2016a; Volkmann et al., 2016b). Thus, scaling down to a single tree or plant, ecohydrological processes related to water uptake and usage are not yet fully understood (Mahindawansha et al., 2018; Sprenger et al., 2019). A widely used tool in ecohydrological research is stable water 
isotope applications. They allow us to investigate and quantify ecohydrological processes such as plant water uptake depth and spatiotemporal patterns of such. The isotopic composition of water allows us to link plant water to its putative water source(s), such as groundwater, precipitation, stream water or (mobile or tightly bound) soil water (Goldsmith et al., 2012; Kübert et al., 2020; Orlowski et al., 2016b; Rothfuss and Javaux, 2017). For the separation of water pools based on the concept that potentially each water pool has its own unique stable water isotope signature due to underlying physical or chemical fractionation processes, highly precise and/or frequent stable water isotope measurements are needed (Dubbert et al., 2019; Ehleringer and Dawson, 1992; Evaristo et al., 2015). For tracer experiments, until today it is widely assumed that stable water isotopes $\left({ }^{2} \mathrm{H} /{ }^{1} \mathrm{H}\right.$ and ${ }^{18} \mathrm{O} /{ }^{16} \mathrm{O}$ ) are not altered by adsorption, degradation or delayed when water is taken up by roots (Ehleringer and Dawson, 1992). However, many recent studies report unknown (potentially fractionation) processes which occur before, during or after water uptake by vegetation, e.g., during root water uptake (e.g., Barbeta et al., 2019; Ellsworth and Williams, 2007; Poca et al., 2019; Zhao et al., 2016). However, so far, it remains challenging to precisely quantify such potential fractionation effects on isotope results.

Traditionally isotope composition of soil and xylem water has been obtained by destructive sampling, lab-based water extractions (e.g., for cryogenic vacuum extraction (hereafter abbreviated as cryo)) and subsequent isotope measurements of the extracted water. Destructive extraction methods are critically discussed in the literature in terms of accuracy and effects of soil parameters or interference of organic contamination in laser-based isotope analysis (Araguás-Araguás et al., 1995; Gaj et al., 2017a, b; Millar et al., 2018; Orlowski et al., 2016a, b, 2018a; Sprenger et al., 2015a; Walker et al., 1994). Generally, lab-based water extraction methods rely on destructive sampling of soil and plant material which is not capable for repeated measurements at the same location and is strongly limited in temporal and spatial resolution of measurements (Kübert et al., 2020).

Such limitations can be overcome by high-frequency in situ measuring methods for stable water isotopes which are more and more used in the ecohydrological community. An extensive review on in situ measurement methods for stable water isotopes can be found in Beyer et al. (2020). So far, many in situ measurement methods are based on the vapor equilibrium principal (Wassenaar et al., 2008) and consist of gas permeable membranes (tubes or probes) through which water vapor is directed to a isotope analyser for real-time stable water isotope measurements (Gaj et al., 2016; Marshall et al., 2020; Oerter et al., 2016; Rothfuss et al., 2013; Volkmann et al., 2016a; Volkmann and Weiler, 2014). The sampled water vapor is assumed to be in equilibrium with the liquid water surrounding the probes (soil or xylem). Water isotope standards (liquid and/or soil) or the equation by Majoube (1971) are applied to transfer vapor to liquid sta- ble water isotope ratios and to calibrate the obtained isotope data (see Beyer et al., 2020). Furthermore, for membranebased systems no isotope fractionation could be observed when water vapor passes through the membrane. However, it should be considered that a considerable amount of air/vapor is withdrawn from the soil or xylem media by the necessary flow rates of the isotope analyser.

Continuous in situ stable water isotope measurements can provide data in high temporal resolution for relatively low monitoring costs with high accuracy (Volkmann and Weiler, 2014). Thus, these methods potentially can provide the measuring accuracy needed to clarify the ongoing discussions about ecohydrological separation (Berry et al., 2018) and help to unravel high-frequency temporal and spatial dynamic processes occurring at the soil-plant-atmosphere interfaces. Such processes can further encompass changes in plant water storage and water travel times from the tree to the ecosystem scale. However, in situ measurements have been applied to trees in only very few cases so far (Marshall et al., 2020; Volkmann et al., 2016a). Interpreting these results is sometimes challenging due to the complex boundary conditions that are given in natural forest environments. An application on a range of species with different vessel and wood anatomies, as well as applications over longer time periods such as weeks or even months, is also still lacking.

Here, we use in situ stable water isotope probes developed and tested by Volkmann and Weiler (2014) and Volkmann et al. (2016b) in a semi-controlled outdoor pot experiment with 20 -year-old trees over the duration of 10 weeks. We test the application of the new in situ measuring method for three different tree species having different anatomies (diffuseporous vs. ring-porous, shallow vs. deep root system). The aim of our research is to learn more about ecohydrological travel times, namely, the time water travels along the soilplant continuum from the roots to the tree stem and further to the canopy. These ecohydrological travel times are particularly relevant to better understand water uptake strategies, source water depths, and delays between root water uptake and transpiration at the tree crown. Furthermore, more and better information on ecohydrological travel times is needed to evaluate and to further improve ecohydrological models (Knighton et al., 2020).

So far, tree water uptake is most commonly indirectly estimated by using sap flow velocities measured at one location of the stem (often breast height) to derive the travel time that water travels from the roots to the canopy. We hypothesize that measuring the actual breakthrough of a tracer (e.g., deuterium) that is transported in the tree xylem is a more direct measurement of ecohydrological travel times. However, for detecting such an isotope tracer breakthrough, highfrequency measurements at the same monitoring location over multiple weeks are a prerequisite. This cannot be accomplished via destructive sampling of soils and tree xylem. The tracer-based travel time approach has the advantage that it can be applied between any two points of the soil-root- 
stem-branch water flow system of a tree. The temporal delay with which the labeled soil water appears in the tree stem and twigs will allow for new insights into plant water uptake strategies. This delay has often been neglected when relating soil water isotope composition to the isotope composition in trees to derive root water uptake profiles.

Specifically, we tested the following research questions:

- Can the new in situ stable water isotope monitoring technique capture the isotope tracer arrival during a controlled labeling experiment and thus allow us to derive ecohydrological water travel times in the soil-tree continuum?

- Can the new in situ stable water isotope monitoring technique be successfully applied to different tree species having different anatomies?

- How do the in situ stable water isotope measurements compare to destructive sampling techniques (cryogenic vacuum extraction and direct water vapor equilibration) that previously have been used for stable water isotope measurements in tree xylem and soils?

\section{Methods}

\subsection{Experimental setup}

Our experimental setup consisted of a semi-controlled outdoor pot experiment with three approximately 20 -year-old 4 to $6 \mathrm{~m}$ high trees. One was a coniferous tree, i.e., Pinus pinea, and two were deciduous trees, i.e., Alnus incana and Quercus suber, which from here on are referred to as Pinus $(P)$, Alnus $(A)$ and Quercus $(Q)$. The trees were planted into large pots $(1.3 \mathrm{~m} \times 0.75 \mathrm{~m} \times 0.5 \mathrm{~m})$ and the soil was covered with rainout shelters (Fig. 1). The pots were filled with a fertile loess soil (Ut2, slightly clayey silt, according to the German Soil Classification KA5, Table 1) from a field site in Malterdingen, Germany. To monitor soil water conditions, we installed soil moisture sensors (Decagon 5TE sensors, Labcell Ltd., USA) in 15 and $30 \mathrm{~cm}$ soil depth and soil matric potential sensors (MPS sensors, Decagon Devices, USA) in $15 \mathrm{~cm}$ soil depth. In the same soil depths $(15$ and $30 \mathrm{~cm}$ ), we also installed the in situ stable water isotope probes (for technical details and installation procedure, see Sect. 2.3 about in situ probes), which in the following are called S15 and S30. Stable water isotope probes were also installed in 15 and $150 \mathrm{~cm}$ stem height in trees' xylem (called X15 and X150 in the following). Trees were equipped with sap flow sensors (SF3 threeneedle HPV sensor, East 30 Sensors, USA) slightly above the isotope probes to avoid sensor measurement influences. All data were logged every $10 \mathrm{~min}$. Meteorologic conditions (i.e., air temperature and precipitation) were measured on site (technical campus of University Freiburg and at an official weather station of the German Weather Service (DWD) less than $1 \mathrm{~km}$ away (station ID: $1443 ; 48.0232^{\circ} \mathrm{N}, 7.8343^{\circ} \mathrm{E}$;

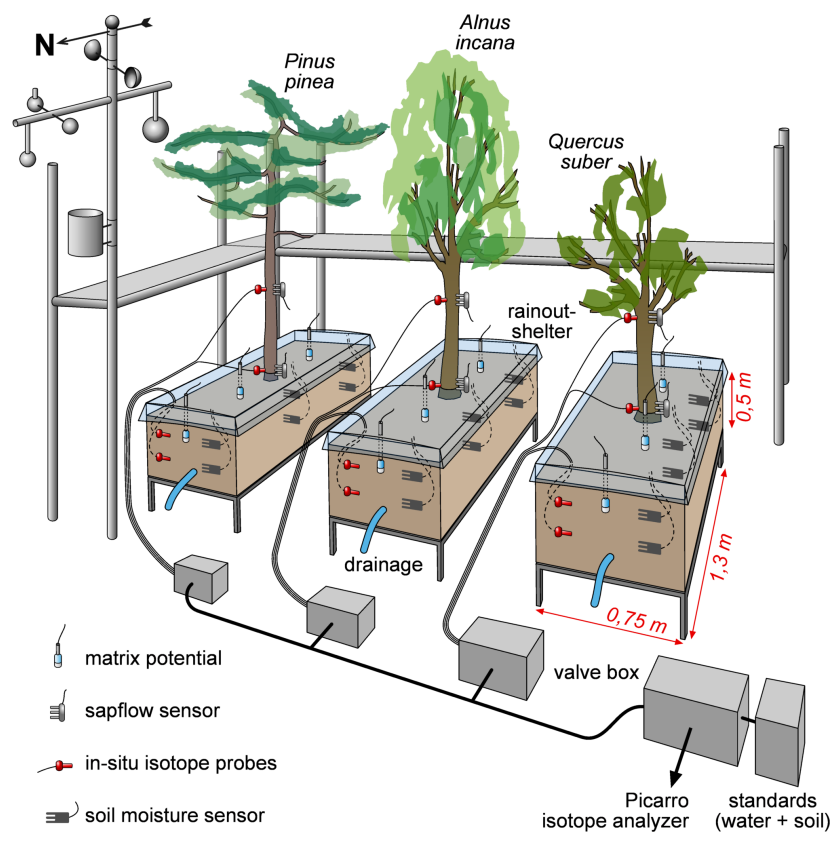

Figure 1. Experiment setup including used sensors and probes as well as the valve and tube setup for the stable water isotope probes. Trees were exposed to outdoor conditions except for natural rainfall, which was to prevent unknown water input into the soil. Note that scales for tree heights or equipment are not representative.

Table 1. Characteristics of the soil used for the experiment. Note that grain size distribution was analyzed after removing the carbonate content with hydrochloric acid.

\begin{tabular}{llr}
\hline Parameter & & Value \\
\hline & coarse sand & $0.5 \%$ \\
& middle sand & $1.9 \%$ \\
Grain size distribution & fine sand & $7.4 \%$ \\
& silt & $81.3 \%$ \\
& clay & $8.9 \%$ \\
\hline German Soil Classification (KA5) & & Ut2 \\
\hline Carbon content & fine grained & $18.5 \%$ \\
\hline pH & & 8.2 \\
\hline Max water storage capacity* & & $63.5 \%$ \\
\hline \multirow{2}{*}{ König (2014). } & & \\
\hline
\end{tabular}

elevation $237 \mathrm{~m}$, temporal resolution: $10 \mathrm{~min}$ ). A scaffolding was set up around the tree pots in order to be able to install and maintain the setup and take destructive samples during the experiment (Fig. 1). 
Table 2. Characteristics of the irrigation and labeling water during the experiment. (Note that the first labeling was split into labeling 1a and $1 \mathrm{~b}$ to better monitor the response in soil moisture. During the second labeling this procedure was no longer necessary.)

\begin{tabular}{llrrr}
\hline Applied water & Date and time (LT) & Amount [mm] & $\delta^{2} \mathrm{H}[\%$ ] & $\delta^{18} \mathrm{O}[\%$ o $]$ \\
\hline Precipitation before experiment* & 2 July 2019 to 20 August 2019 & 155 & -28.8 & -4.2 \\
Irrigation tap water & 4 September 2019 & 20 & -63.1 & -9.2 \\
Labeling 1a & 17 September 2019, 21:15 & 20 & +41.2 & -9.2 \\
Labeling 1b & 18 September, 10:30 & 20 & +41.2 & -9.2 \\
Labeling 2 & 10 October 2019, 20:30 & 40 & +95.1 & -9.2 \\
\hline
\end{tabular}

* Manual event-based samples taken at a roof-top sampling station at the Chair of Hydrology laboratory, University of Freiburg, Germany Amount refers to total precipitation.

\subsection{Irrigation labeling experiments}

The experiment consisted of two irrigation/labeling events in fall 2019 with two differently deuterated waters $(+40 \%$ o $\delta^{2} \mathrm{H}$ and $+95 \% \circ \delta^{2} \mathrm{H}$, Table 2). During the 4 weeks prior to the experiment, trees were irrigated only once with water of a known isotopic composition to reduce the amount of antecedent water in the soil. The first labeling took place in the evening of 7 September and in the morning of 8 September 2019 with two times $20 \mathrm{~mm}$ labeling water $(\mathrm{sum}=40 \mathrm{~mm}$ ) with an isotopic signature of $+40 \% \circ \delta^{2} \mathrm{H}$ (Table 2). During the first labeling, we split the total applied amount of label water into two rounds of irrigation to be able to better monitor the arrival in soil water content. This procedure did not prove to be necessary and was thus not applied for the second labeling, which took place in the evening of the 11 November 2019. We applied a total amount of $40 \mathrm{~mm}$ water with an isotope signature of $+95 \% \circ \delta^{2} \mathrm{H}$. For both labeling, we did not modify the $\delta^{18} \mathrm{O}$ composition (Table 2). To avoid saturated soil conditions at the bottom of the pots, a drainage system was installed but no drainage water was captured from these outlets during the entire experiment.

\subsection{In situ stable water isotope monitoring}

For the in situ stable water isotope monitoring, we used probes similar to Volkmann and Weiler (2014) but with a shorter probe head (length: $30 \mathrm{~mm}$ ). The probes consist of two parts: a hydrophobic microporous polyethylene probing tube (outer diameter: $10 \mathrm{~mm}$; length: $30 \mathrm{~mm}$; Porex Technologies, Germany) and a mixing chamber (Volkmann et al., 2016a). A carrier gas (synthetic dry air) was directed at a rate of $35 \mathrm{~mL} \mathrm{~min}^{-1}$ through a Teflon tube into the tip of the porous membrane of the probe. There, the carrier gas equilibrates with the vapor in the xylem/soil surrounding the probe. Consequently, the equilibrated carrier gas was directed via Teflon tubes into a cavity ring-down isotope analyser ( $\mathrm{Pi}$ carro L1102-i, Picarro Inc., USA). To prevent condensation in the Teflon tube, the equilibrated carrier gas was diluted with synthetic dry air in the mixing chamber to lower the vapor content of the sampling gas. The total flow rate was $35 \mathrm{~mL} \mathrm{~min}^{-1}$ of which $10 \mathrm{mLmin}^{-1}$ was diluted during the measurement. Before each in situ stable water isotope measurement, the tubing system was flushed for 10 to $30 \mathrm{~min}$ to prevent contamination of the isotope measurement by residual moisture in the tubing system. For more technical details, the reader is referred to Volkmann and Weiler (2014).

For the probe installation in the tree xylem, the bark was removed, and a $3 \mathrm{~cm}$ deep hole with a diameter of $1 \mathrm{~cm}$ was drilled into the tree stem. The holes in the trees were deep enough to fit the microporous membrane heads of the isotope probes. The hole with the probe was finally sealed airtight with silicone, which was left to dry for a couple of days before the first isotope measurements.

To allow for later conversion of the vapor isotope measurements into liquid water isotope values, we used a set of isotope standards on site. The isotopic signature of these standards was repeatedly measured over the course of each day to be able to later compensate for any effect on isotope measurements that was potentially caused by applying the method in an outdoor and not in a lab environment. We used two types of standard boxes: airtight PVC tubes filled with soil and added water of a known isotopic signature (standard) and airtight PVC tubes with an air-filled headspace over the isotope standard in liquid form. For each soil standard, $1200 \mathrm{~g}$ soil of the same soil as in the tree pots was dried at $200^{\circ} \mathrm{C}$ for $24 \mathrm{~h}$ (cooled down in a desiccator) and filled into custom-made PVC U-boxes (KGU 125, Ostendorf KG, Germany; length: $14 \mathrm{~cm}$, diameter: $12.5 \mathrm{~cm}$ ) (Orlowski et al., 2013, 2016a, b; Sprenger et al., 2016b; Beyer et al., 2020). The soil was rewetted with $300 \mathrm{~mL}$ of three different standard waters (Table 3 ). The water standard tubes were filled with $150 \mathrm{~mL}$ of water from the same three standards. In each standard tube, one in situ isotope probe was installed and the tubes were sealed airtight. The standard tubes were placed in a Styrofoam box to exclude sunlight and minimize temperature effects. Soil moisture content and temperature in each standard tube were monitored using 5TE probes (Labcell Ltd., USA). This setup allowed for the compensation for any effect of daily temperature fluctuation on the isotope measurements as a matter of the outdoor setting of the experiment.

For reliable isotope measurements, the in situ isotope probe and the connected tubing were first flushed with syn- 
Table 3. Soil and water standards for in situ stable water isotope measurements.

\begin{tabular}{llcr}
\hline Name & Type & $\delta^{2} \mathrm{H}[\%$ o $]$ & $\delta^{18} \mathrm{O}[\%$ o \\
\hline stdSL/stdWL & soil/water low & -82.0 & -11.4 \\
stdSM/stdWM & soil/water middle & -31.9 & -8.2 \\
stdSH/stdWH & soil/water high & +19.9 & -5.0 \\
\hline
\end{tabular}

thetic dry air for 10 to $30 \mathrm{~min}$. Then a valve system facilitated a continuous flow of sampling gas from the in situ isotope probe to the Picarro isotope analyser. Measurements in the sampling mode were carried out until the isotope readings reached a stable plateau. A final data point was calculated based on the median of all reliable measurements of the last 4 min of stable readings. Reliable data were defined by criteria such as isotopic signal in possible range and successful flushing with dry air.

The standard's vapor isotopic signals were related to liquid isotopic signals by measuring the liquid isotopic signal of the standards before and after the experiment (liquid ring-down spectrometer or cryogenic vacuum extraction and vapor equilibrium method). In a second step, the continuous measurements of the standards were used to transform measured in situ stable isotope measurements from vapor to liquid isotopic signals. Isotope data were further corrected for changes in the humidity using the approach by Brand et al. (2009). Finally, the entire isotope dataset was further checked for outliers. We used an agglomerative clustering method combined with a single linkage method (Almeida et al., 2007; Hawkins, 1980) for each isotope probe's data to identify potential outliers. Nearest neighbors were detected with Euclidean distance and, maximum clusters were numbers of observations divided by 10 . Outliers were manually checked and removed if they were deemed to be unreliable.

\subsection{Destructive sampling: cryogenic vacuum extraction and direct water vapor equilibration method}

One aim of our work was to compare the in situ stable water isotope measurements with isotope values obtained by commonly used destructive water (vapor) extraction (equilibration) methods. We chose the cryogenic vacuum extraction (Araguás-Araguás et al., 1995) and the direct water vapor equilibration methods (Sprenger et al., 2015a, b; Stumpp and Hendry, 2012; Wassenaar et al., 2008), which have not been compared with such long and continuous in situ plant water isotope values before.

For obtaining isotope samples for the direct water vapor equilibration method, twigs were collected from the tree crown at four different days during the experiment (Table 4). The bark was removed from the twigs and the samples (at least $30 \mathrm{~g}$ ) were placed in airtight coffee bags ( $1 \mathrm{~L}$ volume, item no. CB400-420 BRZ, Weber Packaging, Germany). Soil samples were taken from soil cores from 0 to $25 \mathrm{~cm}$ and 25 to
Table 4. Dates of destructive sampling campaigns for consecutive cryogenic vacuum extraction ("cryo") (Orlowski et al., 2018b) and the direct water vapor equilibration method ("direct equilibration") (Wassenaar et al., 2008). Samples were collected before noon and directly stored in airtight bags or glass tubes and kept cool $\left(4^{\circ} \mathrm{C}\right)$ until further analysis.

\begin{tabular}{llll}
\hline No. & Date & Type & Method \\
\hline 1 & 16 September 2019 & soil \& xylem & direct equilibration \& cryo \\
2 & 2 October 2019 & soil \& xylem & direct equilibration \\
3 & 28 October 2019 & xylem & direct equilibration \\
4 & 14 November 2019 & soil \& xylem & direct equilibration \& cryo \\
\hline
\end{tabular}

$50 \mathrm{~cm}$ soil depths using a soil sampler (Pürckhauer). Again, samples (at least $30 \mathrm{~g}$ ) were placed in airtight bags. The sampling bags are comprised of tri-ply, adhesive laminated sheets including a $12 \mathrm{~mm}$ layer of aluminum foil and a zip-seal, both guaranteeing airtightness. Sprenger et al. (2015a) showed the suitability of these bags for soil samples and subsequent isotope analysis.

The airtight sampling bags filled with the twig or soil samples were inflated with dry air (pressure about 1 bar) and sealed. The dry air was then allowed to equilibrate with the moisture of the twig/soil sample for 1 (twigs) or 2 (soils) days at $20^{\circ} \mathrm{C}$ lab temperature. For stable water isotope measurements of the airtight bags, a silicone drop was placed on the bag, dried for a day and then punctured with a syringe that was attached to a labbased isotope analyser (Picarro L2120-i, Picarro, USA) via a Teflon tube. To transfer vapor isotope values into liquid isotope values, three internal standards of $10 \mathrm{~mL}$ each (called FSM: $\delta^{2} \mathrm{H}=-126.2 \% o, \delta^{18} \mathrm{O}=-16.7 \%$; tap water: $\delta^{2} \mathrm{H}=-65.9 \%$, $\delta^{18} \mathrm{O}=-9.6 \%$; Baltic Sea: $\delta^{2} \mathrm{H}=$ $-2.6 \%$ o, $\delta^{18} \mathrm{O}=-0.4 \%$ o) were filled in airtight bags, and the isotopic composition was measured in the same way as for the twig/soil samples.

For cryogenic water extraction, we used a custom-built setup at the laboratory of the Chair of Tree Physiology, University of Freiburg (temperature water bath: $95^{\circ} \mathrm{C}$, time: 90 min; for further information, see Dubbert et al., 2014, 2017). This facility participated in the round-robin by Orlowski et al. (2018b). The sampled twig and soil samples were placed into gastight $12 \mathrm{~mL}$ septum-capped glass vials (LABCO, United Kingdom) and heated for $90 \mathrm{~min}$ in a $95^{\circ} \mathrm{C}$ hot-water bath under a vacuum of at least 0.08 mbar. Extracted vapor was trapped in glass tubes cooled with liquid $\mathrm{N}_{2}$. After defrosting, samples were filtered.

Liquid isotope samples (from irrigation water, labeling water, soil and plant water extracts) were analyzed using a L2130-i laser spectroscope (Picarro Inc., Santa Clara, CA, USA) in the laboratory of the Chair of Hydrology. All runs included three in-house standards, which were calibrated against V-SMOW, SLAP, and GISP (IAEA, Vienna) following Newman et al. (2009). This further allowed for drift and 
memory corrections. Isotopic ratios are reported in per mil $(\% o)$ relative to the Vienna Standard Mean Ocean Water (VSMOW) (Craig, 1961). The deuterium excess was calculated as $d=\delta^{2} \mathrm{H}-8 \times \delta^{18} \mathrm{O}$ (Dansgaard, 1964). Precision of analyses was $\pm 0.6 \%$ for $\delta^{2} \mathrm{H}$ and $\pm 0.16 \%$ o for $\delta^{18} \mathrm{O}$. Isotope data were checked for spectral interferences using ChemCorrect $^{\mathrm{TM}}$ (Picarro Inc., Santa Clara, CA, USA). In our study, no plant or soil water sample was found to be affected by organic contamination.

For the fourth measurement campaign (Table 4), stable water isotope signatures of cryogenically extracted water were additionally measured with a mass spectrometer (Delta plus XP; Thermo Finnigan, USA) following the measurement routine described by Saurer et al. (2016) (precision: $1.5 \%$ of $\delta^{2} \mathrm{H}$ and $0.2 \%$ for $\delta^{18} \mathrm{O}$ ).

\subsection{Sap flow data postprocessing}

Heat pulse signals of the sap flow sensors (SF3 three-needle HPV Sensor, East 30 Sensors, USA) were converted into velocities following the Eq. (1) by Hassler et al. (2018), who derived their equation from (Campbell et al., 1991):

$V_{\text {sap }}=\frac{2 k}{C_{\mathrm{w}}\left(r_{\mathrm{u}}+r_{\mathrm{d}}\right)} \ln \left(\frac{\Delta T_{\mathrm{u}}}{\Delta T_{\mathrm{d}}}\right)$,

where $k$ is the thermal conductivity of the sapwood, set to $0.5 \mathrm{~W} \mathrm{~m}^{-1} \mathrm{~K}^{-1} ; C_{\mathrm{w}}$ is the specific heat capacity of water in $\mathrm{J} \mathrm{m}^{-3} \mathrm{~K}^{-1} ; r$ is the distance between heating (middle) and measuring (outer) needles in meters (here $6 \mathrm{~mm}$ ); and $\Delta T$ is the temperature difference before heating and $60 \mathrm{~s}$ after the heat pulse in kelvin. Indices $d$ and $u$ stand for downwards and upwards compared to the heated needle in the middle.

Sap flow velocity was additionally corrected for wounding of the xylem tissue and installation effects using Eq. (2) according to Burgess et al. (2001):

$V_{\mathrm{c}}=b V_{\mathrm{sap}}+c V_{\mathrm{sap}}^{2}+d V_{\mathrm{sap}}^{3}$,

where $V_{\mathrm{c}}\left(\mathrm{m} \mathrm{s}^{-1}\right)$ is the corrected $V_{\text {sap }}$, and $b, c$ and $d$ are the correction coefficients. In line with Hassler et al. (2018), we set $b=1.8558, c=-0.0018 \mathrm{~s} \mathrm{~m}^{-1}$ and $d=0.0003 \mathrm{~s}^{2} \mathrm{~m}^{-2}$ (Burgess et al., 2001; Hassler et al., 2018). Outliers were removed by applying a $30 \mathrm{~min}$ rolling median to the dataset. General offsets were corrected by shifting values in a way that nightly sap flow velocities were zero following Pfautsch et al. (2010).

\subsection{Travel time estimation}

To analyze the isotope tracer arrivals after the labeling events, the tracer arrival times at the in situ isotope probes in 15 and $150 \mathrm{~cm}$ stem height were derived. The tracer arrival time was determined as the first time step after the labeling for which $\delta^{2} \mathrm{H}$ isotope values exceeded the range of isotope values in the $48 \mathrm{~h}$ before the labeling. We also determined the time step of the highest isotope measurement after the labeling (called peak time in the following). Due to a short data gap right after the second labeling in November, we did not include these data but focused our analysis only on the first labeling experiment.

We compared the tracer-based travel times with sap-flowbased travel times for which we calculated cumulated sap flow using sap flow velocity data of Pinus and Alnus sap flow sensors in 15 and $150 \mathrm{~cm}$ stem height. The sap flow data of Quercus was considered as not reliable and excluded from the analysis. We speculate this could be due to the ringporous sapwood structure (see also Bush et al., 2010; Clearwater et al., 1999). We then determined the time step for which cumulated sap flow was equal to the travel distance from an average rooting depth of $15 \mathrm{~cm}$ below surface to 15 and $150 \mathrm{~cm}$ stem height (i.e., 30 and $165 \mathrm{~cm}$ travel distance).

\section{Results}

\subsection{Dynamics of climatic, soil moisture and sap flow conditions}

During the experiment, average air temperature at the experimental site was $14.0^{\circ} \mathrm{C}\left(\mathrm{SD}: 4.4^{\circ} \mathrm{C}\right)$ ranging from $4.0^{\circ} \mathrm{C}$ on the coldest day to $28.2^{\circ} \mathrm{C}$ on the hottest day (Fig. 2). Vapor pressure deficit (VPD) as relevant plant activity indication was highest between 13:00 and 15:00 CET with average values around $0.84 \mathrm{kPa}(\mathrm{SD}: 0.6 \mathrm{kPa})$, reaching maximum values around of $2 \mathrm{kPa}$ for a few days. Soil temperatures in both depths of all pots followed air temperatures trends, although the amplitude was approximately 10 times less pronounced and up to $10 \mathrm{~h}$ delayed. During the experiment, the mean soil temperature for all sensors was $15.1{ }^{\circ} \mathrm{C}\left(\mathrm{SD}: 2.7^{\circ} \mathrm{C}\right)$.

Soil moisture dynamics were only affected by artificial irrigation and the labeling campaigns, since rainout shelters prevented natural precipitation to enter the tree pots. Thus, irrigation with labeled water caused the average volumetric water content (VWC) to increase by $24 \%$ across all trees (Fig. 4). Soil moisture differed between sensors of the same pot and was highest for Quercus (range of average VWC values: $12.2 \%-32.4 \%)$ and smaller for the Pinus pot $(9.6 \%-$ $24.5 \%)$ and the Alnus pot (13.0\%-18.5\%) (Fig. 4). Furthermore, median VWC was highest for Quercus $(20.8 \%)$ and lower for Pinus (11.7\%) and Alnus (14.2\%). Generally, matric potential values exceeded permanent wilting point (PWP) more often for Alnus and Pinus than for the Quercus soil pot (Fig. 4). In $77 \%$ of all soil moisture profiles across all tree pots, we observed higher VWC at $15 \mathrm{~cm}$ than at $30 \mathrm{~cm}$ soil depth. The installed drainage system at the bottom never showed any outflow.

Soil matric potential showed a similar dynamic compared to VWC: starting at $\mathrm{pF}$ values around 2 after labeling/irrigation and increasing during dry periods (up to 3.2 for Pinus, 4.2 for Alnus and 3.2 for Quercus before the sec- 

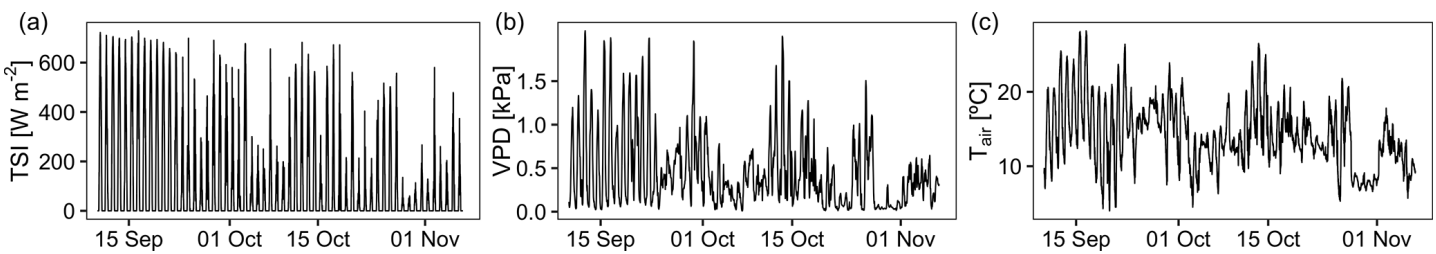

Figure 2. Weather conditions for the study site over the course of the experiment. Data are provided by the German Weather Service station Freiburg im Breisgau, Germany, less than $1 \mathrm{~km}$ away.

ond labeling; up to 4.4 for Pinus, up to 5 (measurement limit) for Alnus, and 3.5 for Quercus at the end of the experiment). Generally, $\mathrm{pF}$ values increased fastest and strongest for $\mathrm{Al}$ nus, while matric potentials in the Quercus pot showed the smallest increase (max pF value 3.4). Over the experimental period, median $\mathrm{pF}$ values were 2.4 for Pinus, 3.2 for Alnus and 2.1 for Quercus (Fig. 4).

The highest sap flow velocities were measured in Pinus at $150 \mathrm{~cm}$ height $\left(\max 12 \mathrm{~cm} \mathrm{~h}^{-1}\right.$, median $\left.=1.9 \mathrm{~cm} \mathrm{~h}^{-1}\right)$, while Alnus showed lower maximum sap flow velocities (at $150 \mathrm{~cm}$ height: $7.4 \mathrm{~cm} \mathrm{~h}^{-1}$, median $=0.8 \mathrm{~cm} \mathrm{~h}^{-1}$ ) over the experimental period. A maximum sap flow velocity of $2.1 \mathrm{cmh}^{-1}$ was measured for Quercus, which is likely due to sensor failure (Fig. 4). Therefore, we excluded this data from further analysis.

\subsection{Isotopic tracer arrival in soils and trees}

The $\delta^{2} \mathrm{H}$ values of all in situ isotope probes before the first labeling in soils and trees were ca. $-30 \%$ ond therefore similar to the $\delta^{2} \mathrm{H}$ values of summer precipitation of the preceding weeks (-29\%o) (Fig. 3). The first labeling on the 17 September 2019 caused a rapid increase of the isotopic signature measured with the soil probes in each pot (see Fig. 3, Table 5). In the Pinus pot, the labeling water first infiltrated into the upper part (first response of isotope tracer after $5 \mathrm{~h}$ ) and reached deeper soil depth with a delay of $2 \mathrm{~d}$. In the $A l$ nus and Quercus pots, the upper and lower in situ isotope probes responded after 15 and $17 \mathrm{~h}$ (Alnus) and 3 and $15 \mathrm{~h}$ (Quercus), respectively. All probes reached peaks in isotope signatures after ca. 1 d, except for Pinus S30 and Alnus S15, which showed a slow but steady increase over 2 weeks following the labeling experiment (Table 5). A likely explanation is, that the labeling water was not penetrating the entire soil profile as homogeneously as intended.

For in situ isotope probes in the tree xylem, Quercus showed a clearly different tracer response compared to Pinus or Alnus. Pinus and Alnus X15 responded both within $17 \mathrm{~h}$ and reached a peak $2.9 \mathrm{~d}$ after the first labeling. In $150 \mathrm{~cm}$, Alnus X150 responded after $2.4 \mathrm{~d}$ followed by a peak after 5.9 d. Pinus X150 could not be evaluated because of a data gap shortly after the labeling. For Quercus (X15 and X150), we could not identify a clear first label arrival, but instead the isotopic values increased slowly over time. More clearly were the peaks for the $\delta^{2} \mathrm{H}$ measurements in Quercus X15 and X150, which we measured after $2.3 \mathrm{~d}$ and after $16 \mathrm{~d}$, respectively.

For Pinus and Alnus, the travel time based on cumulated sap flow at $15 \mathrm{~cm}$ was very similar to the corresponding travel times based on first arrival in isotope measurements, i.e., $17 \mathrm{~h}$ for all calculations (Table 5, Fig. 5). For Alnus (X150), the isotope-based travel time was faster than the sap-flowbased travel time ( $2.4 \mathrm{~d}$ vs. $3.7 \mathrm{~d}$, Table 5). For Quercus, we lack reliable sap flow data that is why we could not compare isotope-based and sap-flow-based travel times.

\subsection{Comparison of in situ stable water isotope measurements and destructive sampling techniques}

When comparing in situ isotope data with destructive measurements, the later showed a wider spread of isotope measurements within the same tree species (soil vs. xylem/twigs) than the in situ measurements (Fig. 6). We found clearly different patterns for $\delta^{2} \mathrm{H}$ and $\delta^{18} \mathrm{O}$ values when comparing destructive measurements with in situ measurements. Hence, for one tree species (soil and xylem/twigs values) results for destructive methods showed maximum differences for $\delta^{2} \mathrm{H}$ up to $49.2 \%$ o during one measurement campaign, while $\delta^{18} \mathrm{O}$ showed differences of up to $4.79 \%$. Furthermore, isotope values from in situ measurements of soils and xylem were much more consistent between the three tree pots (soil and xylem) but also among the measurements from the same tree pot, especially under natural abundance (measurements before labeling).

For $\delta^{2} \mathrm{H}$ values, $63 \%$ of the destructive measurements fell outside the $95 \%$ confidence interval of the in situ stable water isotope measurements when considering a $6 \mathrm{~d}$ time slot (centralized on the day of destructive measurement). On average, $\delta$ values for both isotopes were more positive for destructive measurements than for in situ measurements (Fig. 6).

Comparing the differences between destructive and in situ measurements for $\delta^{2} \mathrm{H}$, we found significant differences between the four different measurement campaigns (ANOVA, $p<0.05$ ). However, comparing differences between methods grouped by tree species or measured material (xylem or soil), no significant differences were found. Additionally, both destructive methods, cryogenic vacuum extraction and 

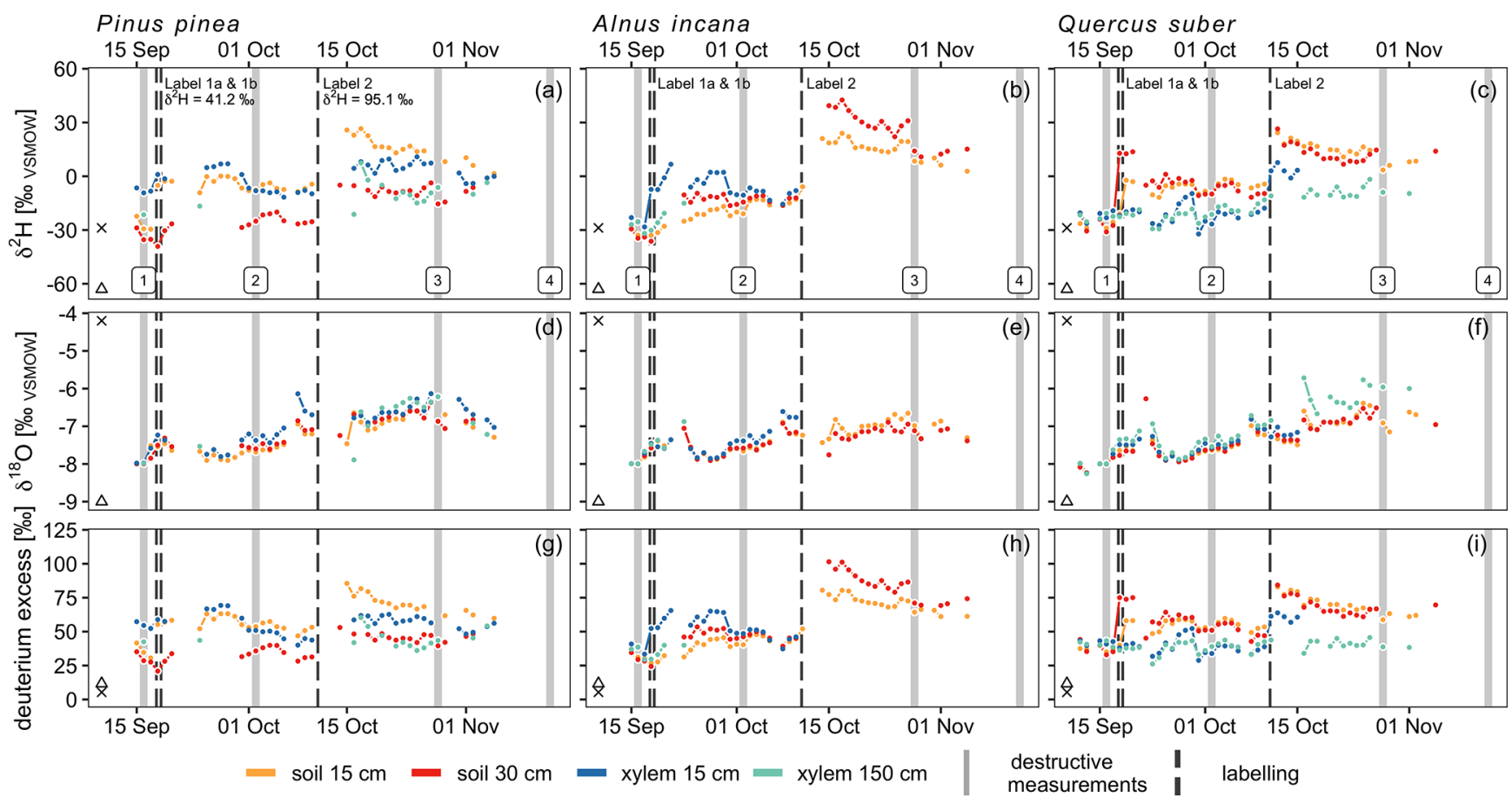

$\times$ summer precipitation before experiment

$\Delta$ pre experiment irrigation

Figure 3. Daily median stable water isotope measurements with in situ probes in xylem and soils. ${ }^{2} \mathrm{H}$ and ${ }^{18} \mathrm{O}$ are shown in $\delta$ notation, while deuterium excess is calculated as follows: $d=\delta^{2} \mathrm{H}-8 \times \delta^{18} \mathrm{O}$ (Dansgaard, 1964). For reference, plots include destructive measurement campaigns (light grey) and labeling dates (dark grey) as well as summer precipitation (cross) and pre-event irrigation isotope signal (triangle). $\delta^{2} \mathrm{H}$ for label 1 was $+41.2 \%$ and $+95.1 \%$ o for label 2 , while $\delta^{18} \mathrm{O}$ was equal to pre-experiment irrigation $(-9.2 \%$ )

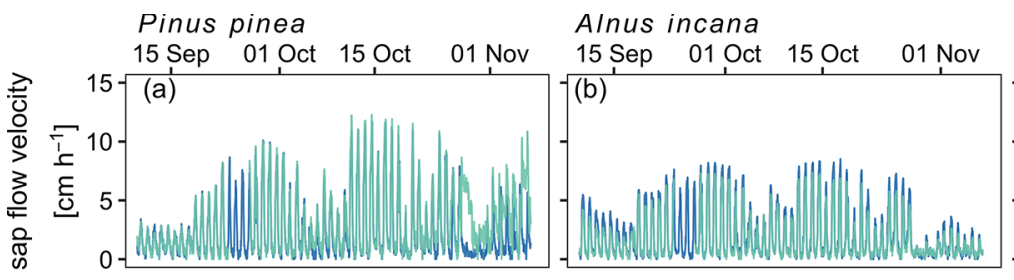

Quercus suber
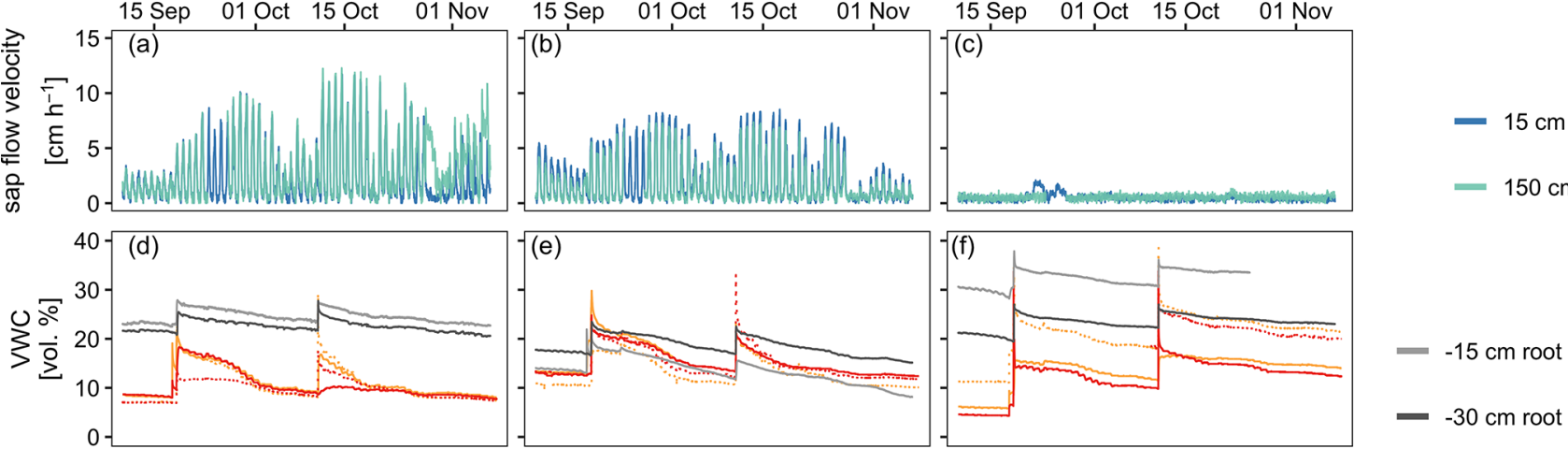

$-150 \mathrm{~cm}$
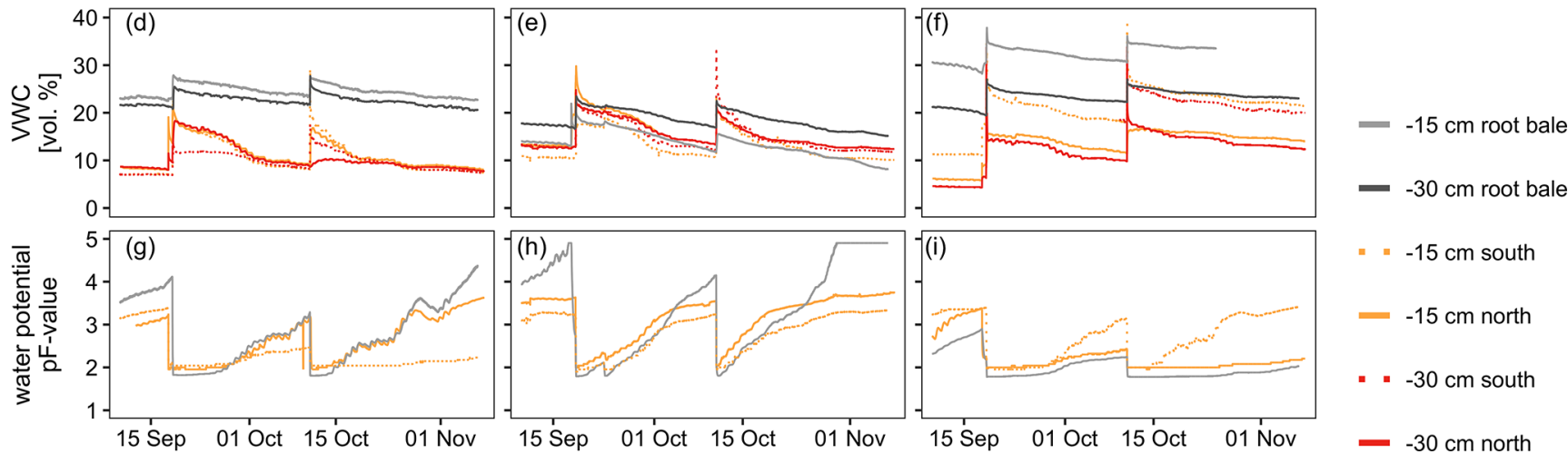

Figure 4. Soil-, tree- and atmospheric conditions over the course of the experiment in 10 min temporal resolution. Soil condition and sap flow velocity is shown for the three tree pots. Sap flow velocity measurements for Quercus suber are most likely affected by sensor failures (panel c). 
Table 5. Tracer arrival and peak times in xylem isotope probes at 15 and $150 \mathrm{~cm}$ height in Pinus, Alnus and Quercus of the first labeling on 17 September 2019. In addition, an estimated time delay based on cumulated sap flow velocity data is given. It is calculated as the time needed for sap to travel from $-15 \mathrm{~cm}$ average rooting depth to 15 and $150 \mathrm{~cm}$ stem height, respectively.

\begin{tabular}{|c|c|c|c|c|c|c|c|c|c|c|}
\hline Tree & Type & $\begin{array}{r}\text { Height } \\
{[\mathrm{cm}]}\end{array}$ & $\begin{array}{r}\delta^{2} \mathrm{H} \\
\text { before } \\
\text { labeling } \\
{[\% \circ]}\end{array}$ & $\begin{array}{r}\delta^{2} \mathrm{H} \\
\text { first } \\
\text { arrival } \\
{[\% o]}\end{array}$ & $\begin{array}{r}\text { Difference } \\
\text { between } \delta^{2} \mathrm{H} \\
\text { before } \\
\text { labeling } \\
\text { and first } \\
\text { arrival [\%o] }\end{array}$ & $\begin{array}{r}\text { Time } \\
\text { delay } \\
\text { first } \\
\text { arrival } \\
\text { [d] }\end{array}$ & $\begin{array}{r}\text { Time } \\
\text { delay } \\
\text { based on } \\
\text { sap flow } \\
\text { [d] }\end{array}$ & $\begin{array}{r}\delta^{2} \mathrm{H} \\
\text { peak } \\
{[\% o]}\end{array}$ & $\begin{array}{r}\text { Difference } \\
\text { between } \\
\delta^{2} \mathrm{H} \text { before } \\
\text { labeling } \\
\text { and peak } \\
\text { [\%o] }\end{array}$ & $\begin{array}{r}\text { Time } \\
\text { delay } \\
\text { peak } \\
\text { [d] }\end{array}$ \\
\hline Pinus & Soil & 30 & -36.40 & -30.42 & 5.98 & 1.9 & & -19.08 & 17.32 & 16.8 \\
\hline Pinus & Soil & 15 & -31.17 & -11.80 & 19.37 & 0.2 & & 8.77 & 39.94 & 0.7 \\
\hline Pinus & Xylem & 15 & -13.37 & 4.99 & 18.36 & 0.7 & 0.7 & 15.11 & 28.48 & 2.9 \\
\hline Pinus & Xylem & 150 & -21.44 & NA & NA & NA & 3.5 & NA & NA & NA \\
\hline Alnus & Soil & 30 & -36.01 & -31.20 & 4.81 & 0.6 & & 9.14 & 45.15 & 1.0 \\
\hline Alnus & Soil & 15 & -35.88 & -30.50 & 5.38 & 0.7 & & -11.12 & 24.76 & 16.4 \\
\hline Alnus & Xylem & 15 & -28.28 & -7.50 & 20.78 & 0.7 & 0.7 & 6.74 & 35.02 & 3.2 \\
\hline Alnus & Xylem & 150 & -32.74 & -19.80 & 12.94 & 2.4 & 3.7 & -13.47 & 19.27 & 5.9 \\
\hline Quercus & Soil & 30 & -32.74 & 3.26 & 36.00 & 0.1 & & 22.73 & 55.47 & 1.0 \\
\hline Quercus & Soil & 15 & -30.39 & -21.22 & 9.17 & 0.6 & & 1.58 & 31.97 & 1.0 \\
\hline Quercus & Xylem & 15 & -23.85 & -19.66 & 4.19 & 0.7 & $X$ & -14.67 & 9.18 & 2.3 \\
\hline Quercus & Xylem & 150 & -22.44 & -18.68 & 3.76 & 3.3 & $X$ & -14.68 & 7.76 & 16.3 \\
\hline
\end{tabular}

NA: no isotope data available, $\mathrm{X}$ : no sap flow data available.

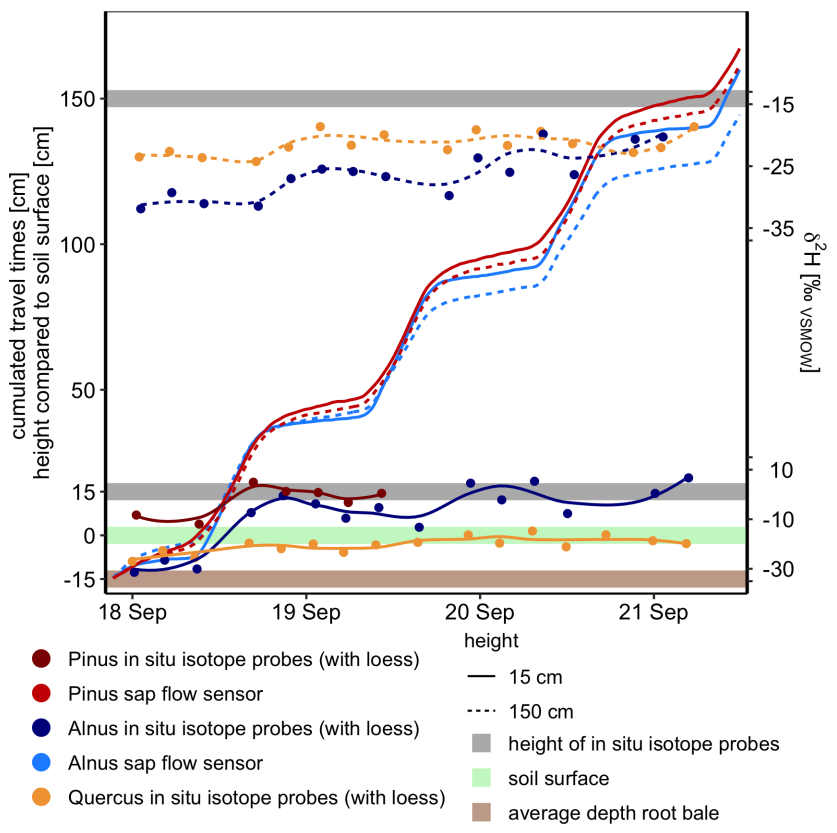

Figure 5. Isotope tracer breakthrough of Alnus, Pinus and Quercus at 15 and $150 \mathrm{~cm}$ stem height and cumulated sap flow of Alnus and Pinus (no reliable sap flow data for Quercus). Tracer-based travel times (i.e., time of first response of isotope tracers) for Alnus and Pinus were similar to sap-flow-based travel times considering the distance from an average rooting depth of $15 \mathrm{~cm}$ below surface to 15 and $150 \mathrm{~cm}$ stem height. direct water vapor equilibration, showed more different results for $\delta^{2} \mathrm{H}$ values than for $\delta^{18} \mathrm{O}$. On average, the measured values for soil samples for $\delta^{2} \mathrm{H}$ and $\delta^{18} \mathrm{O}$ were $13.23 \%$ and $1.35 \%$ more enriched for cryogenic vacuum extraction than for vapor equilibration. However, for xylem/twig measurements most of the $\delta$ values obtained by the vapor equilibration method were higher than the values obtained by cryogenic vacuum extraction (for $\delta^{2} \mathrm{H}, 5$ out of 6 ; for $\delta^{18} \mathrm{O}, 4$ out of 6). Here, average absolute differences were $11.95 \%$ o for $\delta^{2} \mathrm{H}$ and $1.56 \%$ for $\delta^{18} \mathrm{O}$. Additionally, during the last measurement campaign for most samples, the vapor equilibrium method was more enriched in both isotopes.

We cross-checked the cryogenically obtained isotope data on a mass spectrometer. Overall measured samples $(N=12$ for after the second labeling campaign), mean differences between the laser-based isotope measurements and the mass spectrometer measurements were $2.9 \% \circ \pm 1.1 \%$ for $\delta^{2} \mathrm{H}$ and $0.0 \%$ $\pm 0.3 \%$ for $\delta^{18} \mathrm{O}$, which lies in an acceptable range of measurement inaccuracy. Thus, effects of potentially coextracted organics can be ruled out.

\section{Discussion}

Our results suggested that the in situ isotope probes were capable of measuring tracer arrival (and thus water transport) at different locations along the soil-plant continuum in high temporal resolution. This is extremely valuable for monitoring ecohydrological travel times, which were also comparable to travel times derived from our sap flow velocity data. 

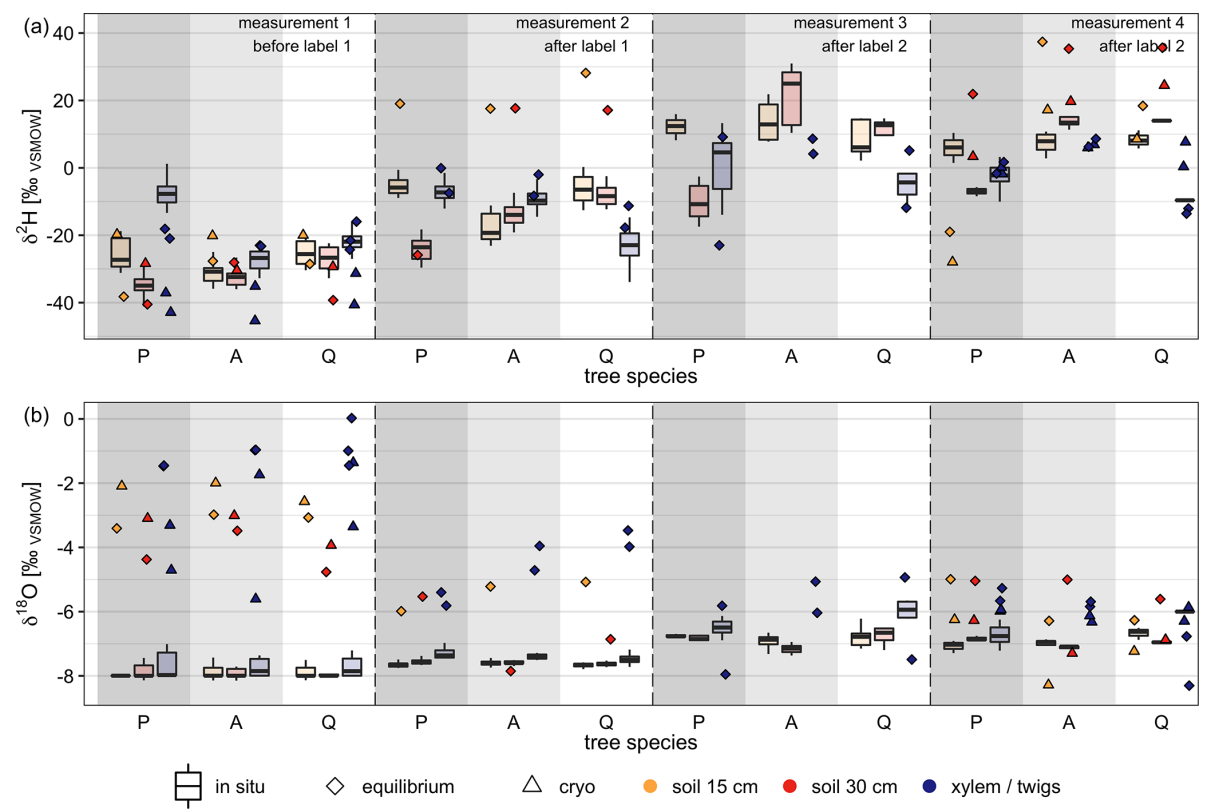

Figure 6. Comparison of destructive isotope measurement methods (direct water vapor equilibration $=$ equilibrium, cryogenic vacuum extraction $=$ cryo) with in situ stable water isotope measurements. Box plots (with median) represent in situ measurements for a $6 \mathrm{~d}$ (on average 11 measurements, range 1 to 41 measurements) time frame around the destructive measurement campaigns. Dates of measurement campaigns and applied methods can be found in Table 4. Tree species on the $x$ axis refer to $\mathrm{P}=$ Pinus pinea, $\mathrm{A}=$ Alnus incana and $\mathrm{Q}=$ Quercus suber. For reference, stable water isotope signature of labeling events, pre-experiment precipitation and pre-experiment irrigation can be found in Table 2 .

In general, in situ isotope probes responded clearly to our applied isotope label, suggesting that the technique was capable to detect rapid changes in isotope composition in soils and tree xylem (see also Seeger and Weiler, 2021; Volkmann et al., 2016b; Volkmann and Weiler, 2014). However, when comparing destructive and in situ measurement methods, we partly observed different results, which we discuss in the following section.

\subsection{In situ stable isotope measurement technique for monitoring ecohydrological travel times}

In general, our measurement approach was capable of detecting differences in isotope composition and tracer arrival in different soil depths (e.g., Pinus and Alnus soil probes) and xylem isotope data of Pinus and Alnus at 15 and Alnus at $150 \mathrm{~cm}$ stem height (data gap for Pinus X150, no immediate response in Quercus X15 and X150). This allowed us to monitor the temporal dynamics of isotope signatures (i.e., tracer breakthrough), including a peak isotope signature at all probes in all three trees. In terms of this tracer breakthrough, we observed a flatter curve at the X150 probes than at the $\mathrm{X} 15$ probes, suggesting that along the flow path, diffusion occurred. This could be caused by temporally trapped water or different flow path lengths and velocities or potential isotope fractionation effects, which decreased the visibility of the isotope tracer signal. Moreover, isotope measurements along extended flow paths might also be subject to potential isotope fractionation processes in the root zone, during water uptake or in the plant (Ellsworth and Williams, 2007; von Freyberg et al., 2020; Poca et al., 2019; Vargas et al., 2017), which would further complicate the interpretation of tracer breakthrough signals. In general, similar effects are also reported by others (Barbeta et al., 2020; Pfautsch et al., 2015; Schepper et al., 2012) and are likely to increase with increasing flow path length. Others have discussed the influence of an exchange of water stored in wood cells and transported in tree xylem (Barbeta et al., 2020; Martín-Gómez et al., 2016). Further research is therefore needed to quantify the importance of these processes for isotope measurements in trees. However, for the detection of the first arrival and a tracer breakthrough of an isotope label, we argue that these processes are likely of minor importance.

\subsection{Isotope-based versus sap-flow-based ecohydrological travel times}

The tracer-based and the sap-flow-based travel times from the root to $15 \mathrm{~cm}$ stem height match well, which suggested that high-frequency in situ isotope measurements can be used to derive ecohydrological travel times in the soil-plant continuum. However, the difference in isotope-based and sapflow-based ecohydrological travel times increased with increasing stem height. Thus, the question of which of the two travel times is more reliable remains. We acknowledge that the tracer signal in the tree xylem is a breakthrough curve that 
allows for some uncertainty in terms of how the first tracer arrival is defined. However, we argue that our definition of the first tracer arrival, namely, a sudden increase in isotope signature that significantly exceeds the natural variability and measuring accuracy observed in the days prior to the experiments, is a reliable indication of the tracer arrival. We further argue that the isotope-based travel time approach is a measure that integrates changing flow conditions along the flow path, e.g., short temporal water storages, while the sapflow-based travel time is an extrapolation based on a point specific measurement. Our data suggest that this difference is trivial for short travel distances but can become relevant already for measurements at breast height $(150 \mathrm{~cm})$. We expect these differences to become even more prominent when calculating travel times from the root to the canopy for entire forest stands (see also Meinzer et al., 2006; Schwendenmann et al., 2010). It is likely that the isotope-based and the sapflow-based ecohydrological travel times differ by the order of several days or even weeks when comparing the two measures in 25 or $50 \mathrm{~m}$ tree height. This is supported by Meinzer et al. (2006), who found sap flow velocities to be five times smaller than tracer-based sap flow velocities in an experiment in coniferous species (tree heights were 13.5 to $58 \mathrm{~m}$ ). Similar results were reported by Schwendenmann et al. (2010), who studied topical trees and bamboo (4.2 to $19.8 \mathrm{~m}$ height, 0.10 to $0.18 \mathrm{~m}$ diameter) and found sap flow velocities measured with a heat dissipation method 7 times smaller than tracer-based estimates.

Parts of these differences in water travel times can likely be explained by the fact that only a fraction of the sapwood cross section consists of conduits and that the specific hydraulic conductivity of latewood is about 1 order of magnitude lower than that of earlywood (Meinzer et al., 2006) In other words, the sap-flow-based velocities are likely underestimating true sap flow. We argue that tracer-based ecohydrological travel times represent a more direct measure of the water transport in trees over longer distances than sap flow based travel times. The difference in isotope arrival between Quercus and the two other tree species in our study also suggests that the in situ isotope technique is capable of measuring tree-species-specific differences in ecohydrological travel times.

\subsection{Differences between tree species}

So far, the in situ measurement method by Volkmann and Weiler (2014) was applied in soils (Volkmann and Weiler, 2014) and a limited number of tree species (maple (Acer campestre) and European beach (Fagus sylvatica)) (Seeger et al., 2020; Seeger and Weiler, 2021; Volkmann et al., 2016a). However, water uptake and transport varies for different tree species depending on multiple factors such as abiotic factors (Fonti and García-González, 2008), vessel width (Hagen-Poiseuille equation) and vessel structure. Clear differences in conifers' xylem structure (e.g., for Pinus pinea) and hardwoods' xylem structure (e.g., Alnus incana, Quercus suber) exist. Conifers are dominated by tracheids which mainly transport water equally within the xylem cross section (Hacke, 2015). On the other hand, hardwoods' xylem consists of twisting non-parallel tracheids (vessels) for nutrition and water transport and wood fiber for stabilization purposes (Kadereit et al., 2014). Here, vessel distribution and thus water transport within the xylem differs between (semi)-ringporous (e.g., Quercus suber) and diffuse-porous (e.g., Alnus incana) tree species. While ring-porous trees tend to build vessels in different sizes, vessels of diffuse-porous trees are more equal in size, which also means a more equal water transport velocity distribution within the xylem (Barij et al., 2011; Kadereit et al., 2014; Leal et al., 2007). Furthermore, it should be mentioned that Quercus suber is a Mediterranean species and does not naturally grow in Germany.

We could identify differences in the dynamics of isotope tracer arrival between tree species that can likely be explained by differences in tree physiology (Figs. 4, 7a and b). When differences for X15 minus the label/irrigation signal are calculated for both stable water isotopes and plotted in dual isotope space, negative $\delta^{2} \mathrm{H}$ values suggest that the tree did not use much of the isotopically enriched water of the label (Fig. 7a and b). Consequently, the trees take up a mixture of labeled and of non-enriched pre-experimental soil water (Table 2). In contrast, for X150, $\delta^{2} \mathrm{H}$ values for all trees were similar. This contrasts with the observed water uptake rates or sap flow velocities for the different tree species (Fig. 4, Table 5). However, for X15, the slower tracer arrival for Quercus (Fig. 3) is visible when looking at the $\delta^{2} \mathrm{H}$ values, which are more negative compared to the other trees (Fig. 7a). Overall, this suggests that with increasing height (X150) the isotopic signal of the water is more similar across all trees regardless of their water uptake quantities.

The same differences can be calculated for the soils (averaged over both depths) and X15 or X150 (Fig. 7c and d). Here, negative numbers in the dual isotope plots show isotopic enrichment in xylem compared to the soil which is especially visible for $\delta^{18} \mathrm{O}$. Differences for $\delta^{2} \mathrm{H}$ in Fig. 7c show that Quercus did not take up as much labeled water as the other trees, since the soil water is more enriched in ${ }^{2} \mathrm{H}$ than the xylem water. This is consistent with our previous findings of a slower decrease in VWC after irrigation (Fig. 4). However, differences between before the first labeling, after the first labeling and after the second labeling measurements were less obvious than in Fig. 7a.

In general, Figs. 3 and 4 suggest that soil water at S15 and S30 was not fully replaced by the labeling water since soil water isotopic composition was not exactly similar to the introduced isotopic label. Thus, the enrichment of xylem water for Pinus and Alnus compared to soil water isotopic composition could be potentially due to plant water uptake of newer and easier available labeling water which contributes only partly to the measured isotopic composition measured with the soil probes. Another source of isotope enrichment 

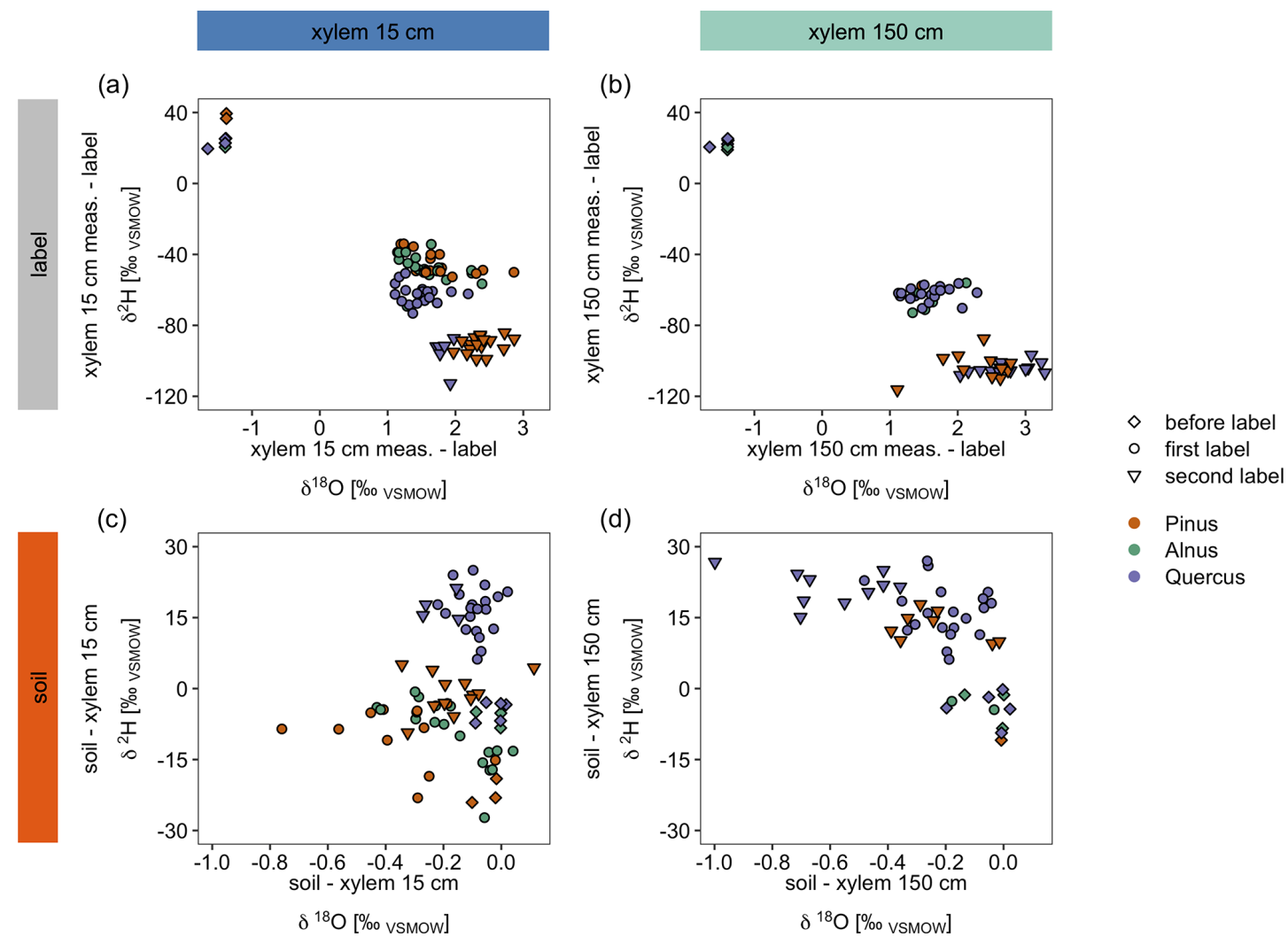

Figure 7. Panels (a) and (b) show differences between daily median in situ stable water isotope measurements and the label water's stable water isotope signature presented in a dual isotope plot. Panels (c) and (d) compare daily median in situ soil measurements (averaged over both soil depths) with the corresponding xylem measurements of the same day. Note that the points "before label" refer to the average value between pre-event precipitation and pre-event irrigation water, while first label and second label refer to the isotopic signal of the label water. See Table 2 for the isotopic compositions.

in xylem water could be fractioning processes during or after plant water uptake. Thus, data from before the labeling experiment show for all trees isotopic enrichment in the xylem water compared to the soil water isotopic composition (Fig. 7c and d). These findings are supported by the ongoing discussion in literature about fractionation processes during plant water uptake (e.g., von Freyberg et al., 2020; Poca et al., 2019; Vargas et al., 2017; Zhao et al., 2016). Thus, we argue that the in situ stable isotope measurement method could be valuable in future research to answer questions regarding isotope fractionation during water uptake by plants.

Furthermore, Fig. 7d suggests, similar to Figs. $7 \mathrm{~b}$ and 5, that the tracer arrival in X150 was less pronounced than in $\mathrm{X} 15$ since soil water was comparably more enriched in ${ }^{2} \mathrm{H}$ than xylem water. The decrease of tracer visibility in X150 was stronger for Pinus than for Quercus (for Alnus insufficient data). Based on our findings, we recommend to manipulate only one isotope of water (either hydrogen or oxygen) since this holds the best chance for a backup and controlling with the unmanipulated isotope (here ${ }^{18} \mathrm{O}$ ).

Additionally, we argue that information about vessel structure or tree reaction to probe installation, such as blocking tracheids due to wounding, should be considered and better investigated in future research. Tissue wounding can cause a decrease in xylem water flow, including the transport of a stable water isotope tracer passing by the in situ stable water isotope probes installed in the tree xylem. Similar observations for different species, e.g., installation of sap flow sensors or impact of outer forces, are shown in literature (e.g., Ballesteros et al., 2010; Barrett et al., 1995; Burgess et al., 2001; Schmitt and Liese, 1993). This is generally consistent with our observations which show less sensor failure for sap flow sensors in the coniferous tree compared to the semiring-porous Quercus suber (Figs. 4 and 6).

For future research, we suggest that in situ stable water isotope probes should be tested in a range of different tree species to better understand influences of tree properties such as xylem structure, reaction to wounding, soil conditions, etc. However, more repetitions per tree species are also indispensable to improve statistical accuracy, since even trees from the same species may respond differently. Using the shorter probe heads $(3 \mathrm{~cm})$ in our study compared to Volkmann and Weiler (2014) $(5 \mathrm{~cm})$ ensured the measurement in the sapwood with active sap flow, which normally takes place 
in the outer $3 \mathrm{~cm}$ of the tree trunk (Caylor and Dragoni, 2009; Cohen et al., 2008; Hacke, 2015).

\subsection{Comparison of in situ and destructive isotope measurements}

Over the course of the experiment, we especially found clear differences between in situ and destructive isotope measurements for ${ }^{18} \mathrm{O}$ that we did not spike but used as "control" stable water isotope. This is likely due to sampling water from different water pools in soil and xylem. Hence, the effect of the sampling method on the isotopic signature of a sample is heavily discussed within the ecohydrological research community (Berry et al., 2018; Beyer et al., 2020; Bowers et al., 2020; Kübert et al., 2020; Orlowski et al., 2019; Penna et al., 2018; Sprenger et al., 2018). Cryogenic vacuum extraction is known to sample bulk soil water but also hygroscopic and biologically bound water (Koeniger et al., 2011; Orlowski et al., 2016b; Sprenger et al., 2015a).

Moreover, comparing results of different methods remains challenging as also shown by other authors (e.g., Millar et al., 2018; Orlowski et al., 2016b). For instance, we found, that $\delta$ values for both isotopes were mostly more positive for the destructive measurements than for in situ measurements. In a method comparison by Orlowski et al. (2016b) over different soil types, the direct water vapor equilibration method showed higher $\delta^{18} \mathrm{O}$ and $\delta^{2} \mathrm{H}$ values in comparison to cryogenic vacuum extraction. Previous studies have further shown that the direct water vapor equilibration method can show a wider spread in isotope data across the same soil type (Orlowski et al., 2019), especially in low water content soils ( $<5 \%$ gravimetric water content of less than $3 \mathrm{~g}$ of water in the sample) and consolidated shales (Hendry et al., 2015; Wassenaar et al., 2008). However, in our study with only few data points for the destructive methods, we did not find differences among the destructive methods we used.

As compared to in situ measurements, $\delta^{18} \mathrm{O}$ values provided by destructive sampling suggest that the latter contains more tightly bound water that was similar to pre-experiment precipitation (Table 2, Fig. 6). This was most apparent for $\delta^{18} \mathrm{O}$ but not for $\delta^{2} \mathrm{H}$ since the applied ${ }^{2} \mathrm{H}$ label in our study likely has masked the effect of sampling from different water pools for the $\delta^{2} \mathrm{H}$ measurements. Kübert et al. (2020) found small differences between in situ measurements and cryogenically extracted isotope values under natural abundance conditions. However, after a strongly enriched ${ }^{2} \mathrm{H}$ label application, the authors observed considerable differences between cryogenically extracted and in situ soil water vapor measurements (following the method of Rothfuss et al., 2013). In our study, the observed differences in the $\delta^{18} \mathrm{O}$ values became smaller over time (Fig. 6). This is most likely due to the fact that the water used for irrigation/labeling (e.g., $\delta^{18} \mathrm{O}=-9.2 \%$ o) became more abundant in smaller pores over the course of the experiment, and the amount of preexperiment precipitation $\left(\delta^{18} \mathrm{O}=-4.2 \%\right.$ ) became smaller over time. This assumption is supported by the more negative $\delta^{18} \mathrm{O}$ values of the destructive samples towards the end of the experiment (Fig. 6).

Regarding isotope measurements in xylem, Millar et al. (2018) argue that cryogenic vacuum extraction accesses the total plant water, resulting in more depleted ${ }^{2} \mathrm{H}$ and ${ }^{18} \mathrm{O}$. However, in our experiment we found that most $\delta$ values of cryogenic vacuum extraction were more negative than from the water vapor equilibration method (Fig. 6). Nevertheless, we are aware of our low number of destructive samplings and therefore focus less on differences between both destructive methods. VWC conditions during the first and last measurement campaign were similar. Thus, a potential effect of VWC would be similar for all methods. Orlowski et al. (2016b, 2019) showed that VWC-differences can strongly influence on results in their lab-based study.

\subsection{Experimental setup}

Our semi-controlled outdoor pot experiment aimed at minimizing potential influences of boundary conditions that typically occur in natural forest environments, e.g., soil heterogeneity, subsurface flow and redistribution of soil water, rainfall input, stemflow, and associated variability in isotope signatures in the soil-tree compartment (see von Freyberg et al., 2020). Typically, variability in outdoor conditions are overcome by working in a greenhouse under controlled conditions with, for example, tree seedlings instead of adult trees and a homogeneous substrate. However, tree seedlings considerably differ in their physiognomic properties compared to mature trees. This was the reason why we used 20 -yearold 4 to $6 \mathrm{~m}$ high trees that are more similar to mature trees.

In general, the variability in our isotope data has shown that outdoor isotope measurements are challenging and that the quality is not comparable to the accuracy gained with lab-based isotope measurements of liquid water. The use of on-site standard boxes (water and soils) that were exposed to the same environmental conditions improved the accuracy of our isotope measurements. The high temporal frequency with which one can measure the isotopic compositions with in situ isotope probes allows for quantification of this environmental variability and for efficient averaging to gain reliable results. We argue that the accuracy is well suited to perform tracer labeling experiments and monitor the tracer arrival that is typically orders of magnitude larger than natural isotopic variability. However, detectability of tracer arrival with increasing stem hight could be improved by even more elevated tracer signals as suggest by Marshall et al. (2020) for a similar tree experiment.

Our in situ measurement setup was able to measure the stable water isotope composition in xylem and soil water in high resolution $\left(>60 \mathrm{~d}^{-1}\right)$ over months and relate this to further monitored environmental parameters (e.g., matric potential, VWC, sap flow). High temporal resolution constitutes an important step towards better understanding of fractionation 
processes or mixing of different water pools in soils and trees (McDonnell, 2014).

\subsection{Conclusions and future implications}

Our semi-controlled outdoor isotope labeling experiment with three different tree species (Pinus pinea, Alnus incana and Quercus suber) proved the applicability of a new in situ stable water isotope measurement approach in soils and tree xylem. However, in situ measurements partly showed different isotopic composition compared to two destructive sampling techniques (cryogenic vacuum extraction and direct water vapor equilibration). This was especially visible for the non-manipulated $\delta^{18} \mathrm{O}$ values. These differences in isotope measurements can likely be attributed to different water pools that are sampled by the in situ measurements and the destructive sampling.

The in situ isotope data were further used to derive ecohydrological water travel times in the soil-tree continuum and to compare those to travel times derived from sap flow measurements. Here, our high temporal resolution measurements of ${ }^{2} \mathrm{H}$ compositions in soils and trees allowed us to identify tree-species-specific differences in ecohydrological travel times. For the lower measurement point at $15 \mathrm{~cm}$ stem height, ecohydrological travel times in tree xylem measured by stable water isotopes were equal to travel times obtained by cumulated sap flow velocity $(0.7 \mathrm{~d}$ from roots to measurement height). However, the difference between the two travel time approaches became larger with increasing travel distance (i.e., $1.3 \mathrm{~d}$ difference for Alnus incana at $150 \mathrm{~cm}$ stem height). We therefore expect travel times based on sap flow measurements to be potentially different by several days when estimating water travel times from the roots to the canopy of a natural forest which might reach up to $40 \mathrm{~m}$ in height or more. Thus, we consider the isotope-tracer-based travel time to be a more direct measure of the actual water flow towards the canopy.

The high accuracy and high temporal resolution of our in situ stable water isotope measurement method can be of great advantage when studying tree temporal water storage dynamics, dispersion processes (in soils and potentially xylem) and differences in water flow pathways through individual plants and related water age differences (e.g., Berry et al., 2018; Dubbert et al., 2019; Sprenger et al., 2016a, 2018, 2019). Furthermore, future studies using in situ measurements could contribute to the discussion of potential changes in the isotope signature during plant water uptake and water flow within the plant xylem related to fractionation processes (e.g., Poca et al., 2019; von Freyberg et al., 2020).

In summary, the presented in situ probes resulted in more consistent measurements of the isotope composition in soils and tree xylem in comparison to traditional destructive measurement. This is particularly important when trying to identify tree-species-specific differences in water uptake strategies and travel times. Moreover, the capability of tracking the isotopic signature from the soil through the tree xylem water (in high temporal resolution in different tree species and soil depths at the same location over several months simultaneously) is a prerequisite for advancing our understanding in terms of plant source water depth and source water age as well as mixing of different water pools along the flow path from the roots to the canopy.

Data availability. The datasets generated for this study are available upon request to the corresponding author.

Author contributions. NO, MR and SS wrote the grant and designed the experiment. DM, SS, NO and MR conducted the field measurements. Data analyses was performed by DM and MR. The article was prepared by DM, NO, MR and SS. All authors reviewed the article.

Competing interests. The authors declare that they have no conflict of interest.

Disclaimer. Publisher's note: Copernicus Publications remains neutral with regard to jurisdictional claims in published maps and institutional affiliations.

Special issue statement. This article is part of the special issue "Water, isotope and solute fluxes in the soil-plant-atmosphere interface: investigations from the canopy to the root zone". It is not associated with a conference.

Acknowledgements. This work was funded by Freiburg's Academic Society. We thank Barbara Herbstritt for lab support and student intern Bernhard Gigler for his help during field campaigns. Hugo de Boer is thanked for plant physiological advice and his help during the experiment setup, and Britta Kattenstroth is thanked for technical support. We further thank the Chair of Ecosystem Physiology for being able to use their greenhouse and cryogenic vacuum extraction facility, the Chair of Hydrology for technical field equipment and Matthias Beyer for the provision of the Alnus and Quercus trees.

Financial support. This study was funded by Freiburg's Academic Society. The article processing charge was funded by the BadenWürttemberg Ministry of Science, Research and Art and the University of Freiburg in the funding program Open Access Publishing.

Review statement. This paper was edited by Josie Geris and reviewed by Sylvain Kuppel and one anonymous referee. 


\section{References}

Almeida, J. A. S., Barbosa, L. M. S., Pais, A. A. C. C., and Formosinho, S. J.: Improving hierarchical cluster analysis: A new method with outlier detection and automatic clustering, Chemometr. Intell. Lab., 87, 208-217, https://doi.org/10.1016/j.chemolab.2007.01.005, 2007.

Araguás-Araguás, L., Rozanski, K., Gonfiantini, R., and Louvat, D.: Isotope effects accompanying vacuum extraction of soil water for stable isotope analyses, J. Hydrol., 168, 159-171, https://doi.org/10.1016/0022-1694(94)02636-p, 1995.

Ballesteros, J. A., Stoffel, M., Bodoque, J. M., Bollschweiler, M., Hitz, O., and Díez-Herrero, A.: Changes in Wood Anatomy in Tree Rings of Pinus pinaster Ait. Following Wounding by Flash Floods, Tree-Ring Res., 66, 93-103, https://doi.org/10.3959/2009-4.1, 2010.

Barbeta, A., Jones, S. P., Clavé, L., Wingate, L., Gimeno, T. E., Fréjaville, B., Wohl, S., and Ogée, J.: Unex-plained hydrogen isotope offsets complicate the identification and quantification of tree water sources in a riparian forest, Hydrol. Earth Syst. Sci., 23, 2129-2146, https://doi.org/10.5194/hess-23-2129-2019, 2019.

Barbeta, A., Gimeno, T. E., Clavé, L., Fréjaville, B., Jones, S. P., Delvigne, C., Wingate, L., and Ogée, J.: An explanation for the isotopic offset between soil and stem water in a temperate tree species, New Phytol., 227, 766-779, https://doi.org/10.1111/nph.16564, 2020.

Barij, N., Čermák, J., and Stokes, A.: Azimuthal variations in xylem structure and water relations in cork oak (Quercus suber), IAWA J., 32, 25-40, https://doi.org/10.1163/2294193290000040, 2011.

Barrett, D. J., Hatton, T. J., Ash, J. E., and Ball, M. C.: Evaluation of the heat pulse velocity technique for measurement of sap flow in rainforest and eucalypt forest species of south-eastern Australia, Plant Cell Environ., 18, 463-469, https://doi.org/10.1111/j.13653040.1995.tb00381.x, 1995.

Berry, Z. C., Evaristo, J., Moore, G., Poca, M., Steppe, K., Verrot, L., Asbjornsen, H., Borma, L. S., Bretfeld, M., HervéFernández, P., Seyfried, M., Schwendenmann, L., Sinacore, K., De Wispelaere, L., and McDonnell, J.: The two water worlds hypothesis: Addressing multiple working hypotheses and proposing a way forward, Ecohydrology, 11, e1843, https://doi.org/10.1002/eco.1843, 2018.

Beyer, M., Kühnhammer, K., and Dubbert, M.: In situ measurements of soil and plant water isotopes: a review of approaches, practical considerations and a vision for the future, Hydrol. Earth Syst. Sci., 24, 4413-4440, https://doi.org/10.5194/hess-24-44132020, 2020.

Bowers, W. H., Mercer, J. J., Pleasants, M. S., and Williams, D. G.: A combination of soil water extraction methods quantifies the isotopic mixing of waters held at separate tensions in soil, Hydrol. Earth Syst. Sci., 24, 4045-4060, https://doi.org/10.5194/hess-24-4045-2020, 2020.

Brand, W. A., Geilmann, H., Crosson, E. R., and Rella, C. W.: Cavity ring-down spectroscopy versus high-temperature conversion isotope ratio mass spectrometry; a case study on $\delta^{2} \mathrm{H}$ and $\delta^{18} \mathrm{O}$ of pure water samples and alcohol/water mixtures, Rapid Commun. Mass Sp., 23, 1879-1884, https://doi.org/10.1002/rcm.4083, 2009.
Brinkmann, N., Seeger, S., Weiler, M., Buchmann, N., Eugster, W., and Kahmen, A.: Employing stable isotopes to determine the residence times of soil water and the temporal origin of water taken up by Fagus sylvatica and Picea abies in a temperate forest, New Phytol., 219, 1300-1313, https://doi.org/10.1111/nph.15255, 2018.

Brooks, J. R., Barnard, H. R., Coulombe, R., and McDonnell, J. J.: Ecohydrologic separation of water between trees and streams in a Mediterranean climate, Nat. Geosci., 3, 100-104, https://doi.org/10.1038/ngeo722, 2010.

Burgess, S. S. O., Adams, M. A., Turner, N. C., Beverly, C. R., Ong, C. K., Khan, A. A. H., and Bleby, T. M.: An improved heat pulse method to measure low and reverse rates of sap flow in woody plants, Tree Physiol., 21, 589-598, https://doi.org/10.1093/treephys/21.9.589, 2001.

Bush, S. E., Hultine, K. R., Sperry, J. S., Ehleringer, J. R., and Phillips, N.: Calibration of thermal dissipation sap flow probes for ring- and diffuse-porous trees, Tree Physiol., 30, 1545-1554, https://doi.org/10.1093/treephys/tpq096, 2010.

Campbell, G. S., Calissendorff, C., and Williams, J. H.: Probe for Measuring Soil Specific Heat Using A HeatPulse Method, Soil Sci. Soc. Am. J., 55, 291-293, https://doi.org/10.2136/sssaj1991.03615995005500010052x, 1991.

Caylor, K. K. and Dragoni, D.: Decoupling structural and environmental determinants of sap velocity: Part I. Methodological development, Agr. Forest Meteorol., 149, 559-569, https://doi.org/10.1016/j.agrformet.2008.10.006, 2009.

Clearwater, M. J., Meinzer, F. C., Andrade, J. L., Goldstein, G., and Holbrook, N. M.: Potential errors in measurement of nonuniform sap flow using heat dissipation probes, Tree Physiol., 19, 681687, https://doi.org/10.1093/treephys/19.10.681, 1999.

Cohen, Y., Cohen, S., Cantuarias-Aviles, T., and Schiller, G.: Variations in the radial gradient of sap velocity in trunks of forest and fruit trees, Plant Soil, 305, 49-59, https://doi.org/10.1007/s11104-007-9351-0, 2008.

Craig, H.: Isotopic Variations in Meteoric Waters, Science, 133, 1702-1703, https://doi.org/10.1126/science.133.3465.1702, 1961.

Dansgaard, W.: Stable isotopes in precipitation, Tellus, 16, 436468, https://doi.org/10.3402/tellusa.v16i4.8993, 1964.

Dubbert, M., Cuntz, M., Piayda, A., and Werner, C.: Oxygen isotope signatures of transpired water vapor: the role of isotopic nonsteady-state transpiration under natural conditions, New Phytol., 203, 1242-1252, https://doi.org/10.1111/nph.12878, 2014.

Dubbert, M., Kübert, A., and Werner, C.: Impact of Leaf Traits on Temporal Dynamics of Transpired Oxygen Isotope Signatures and Its Impact on Atmospheric Vapor, Front. Plant Sci., 8, Article 5, https://doi.org/10.3389/fpls.2017.00005, 2017.

Dubbert, M., Caldeira, M. C., Dubbert, D., and Werner, C.: A poolweighted perspective on the two-water-worlds hypothesis, New Phytol., 222, 1271-1283, https://doi.org/10.1111/nph.15670, 2019.

Ehleringer, J. R. and Dawson, T. E.: Water uptake by plants: perspectives from stable isotope composition, Plant Cell Environ., 15, 1073-1082, https://doi.org/10.1111/j.13653040.1992.tb01657.x, 1992. 
Ellsworth, P. Z. and Williams, D. G.: Hydrogen isotope fractionation during water uptake by woody xerophytes, Plant Soil, 291, 93-107, https://doi.org/10.1007/s11104-006-9177-1, 2007.

Evaristo, J., Jasechko, S., and McDonnell, J. J.: Global separation of plant transpiration from groundwater and streamflow, Nature, 525, 91-94, https://doi.org/10.1038/nature14983, 2015.

Fonti, P. and García-González, I.: Earlywood vessel size of oak as a potential proxy for spring precipitation in mesic sites, J. Biogeogr., 35, 2249-2257, https://doi.org/10.1111/j.13652699.2008.01961.x, 2008.

Gaj, M., Beyer, M., Koeniger, P., Wanke, H., Hamutoko, J., and Himmelsbach, T.: In situ unsaturated zone water stable isotope $\left({ }^{2} \mathrm{H}\right.$ and $\left.{ }^{18} \mathrm{O}\right)$ measurements in semi-arid environments: a soil water balance, Hydrol. Earth Syst. Sci., 20, 715-731, https://doi.org/10.5194/hess-20-715-2016, 2016.

Gaj, M., Kaufhold, S., Koeniger, P., Beyer, M., Weiler, M., and Himmelsbach, T.: Mineral mediated isotope fractionation of soil water, Rapid Commun. Mass Sp., 31, 269-280, https://doi.org/10.1002/rcm.7787, 2017a.

Gaj, M., Kaufhold, S., and McDonnell, J. J.: Potential limitation of cryogenic vacuum extractions and spiked experiments, Rapid Commun. Mass Sp., 31, 821-823, https://doi.org/10.1002/rcm.7850, 2017b.

Goldsmith, G. R., Muñoz-Villers, L. E., Holwerda, F., McDonnell, J. J., Asbjornsen, H., and Dawson, T. E.: Stable isotopes reveal linkages among ecohydrological processes in a seasonally dry tropical montane cloud forest, Ecohydrology, 5, 779-790, https://doi.org/10.1002/eco.268, 2012.

Hacke, U. (Ed.): Functional and Ecological Xylem Anatomy, Springer International Publishing, Cham, 2015.

Hassler, S. K., Weiler, M., and Blume, T.: Tree-, stand- and sitespecific controls on landscape-scale patterns of transpiration, Hydrol. Earth Syst. Sci., 22, 13-30, https://doi.org/10.5194/hess-2213-2018, 2018.

Hawkins, D. M.: Identification of Outliers, Springer Netherlands, Dordrecht, 1980.

Hendry, M. J., Schmeling, E., Wassenaar, L. I., Barbour, S. L., and Pratt, D.: Determining the stable isotope composition of pore water from saturated and unsaturated zone core: improvements to the direct vapour equilibration laser spectrometry method, Hydrol. Earth Syst. Sci., 19, 4427-4440, https://doi.org/10.5194/hess-19-4427-2015, 2015.

Kadereit, J. W., Körner, C., Kost, B., and Sonnewald, U.: Strasburger - Lehrbuch der Pflanzenwissenschaften, Springer, Berlin, Heidelberg, 2014.

Knighton, J., Kuppel, S., Smith, A., Soulsby, C., Sprenger, M., and Tetzlaff, D.: Using isotopes to incorporate tree water storage and mixing dynamics into a distributed ecohydrologic modelling framework, Ecohydrology, 13, e2201, https://doi.org/10.1002/eco.2201, 2020.

König, N.: Gutachterausschuss Forstliche Analytik: Handbuch Forstliche Analytik, available at: https://www.nw-fva.de/ fileadmin/nwfva/publikationen/pdf/konig_handbuch_forstliche. pdf (last access: 16 August 2021), 2014.

Koeniger, P., Marshall, J. D., Link, T., and Mulch, A.: An inexpensive, fast, and reliable method for vacuum extraction of soil and plant water for stable isotope analyses by mass spectrometry, Rapid Commun. Mass Sp., 25, 3041-3048, https://doi.org/10.1002/rcm.5198, 2011.
Kübert, A., Paulus, S., Dahlmann, A., Werner, C., Rothfuss, Y., Orlowski, N., and Dubbert, M.: Water Stable Isotopes in Ecohydrological Field Research: Comparison Between In Situ and Destructive Monitoring Methods to Determine Soil Water Isotopic Signatures, Front. Plant Sci., 11, Article 387, https://doi.org/10.3389/fpls.2020.00387, 2020.

Leal, S., Sousa, V. B., and Pereira, H.: Radial variation of vessel size and distribution in cork oak wood (Quercus suber L.), Wood Sci. Technol., 41, 339-350, https://doi.org/10.1007/s00226-0060112-7, 2007.

Mahindawansha, A., Orlowski, N., Kraft, P., Rothfuss, Y., Racela, H., and Breuer, L.: Quantification of plant water uptake by water stable isotopes in rice paddy systems, Plant Soil, 429, 281-302, https://doi.org/10.1007/s11104-018-3693-7, 2018.

Majoube, M.: Fractionnement en oxygène 18 et en deutérium entre l'eau et sa vapeur, J. Chim. Phys., 68, 1423-1436, https://doi.org/10.1051/jcp/1971681423, 1971.

Marshall, J. D., Cuntz, M., Beyer, M., Dubbert, M., and Kuehnhammer, K.: Borehole Equilibration: Testing a New Method to Monitor the Isotopic Composition of Tree Xylem Water in situ, Front. Plant Sci., 11, 358, https://doi.org/10.3389/fpls.2020.00358, 2020.

Martín-Gómez, P., Serrano, L., and Ferrio, J. P.: Short-term dynamics of evaporative enrichment of xylem water in woody stems: implications for ecohydrology, Tree Physiol., 37, 511522, https://doi.org/10.1093/treephys/tpw115, 2016.

McDonnell, J. J.: The two water worlds hypothesis: ecohydrological separation of water between streams and trees?, Wiley Interdiscip. Rev. Water, 1, 323-329, https://doi.org/10.1002/wat2.1027, 2014.

Meinzer, F. C., Brooks, J. R., Domec, J.-C., Gartner, B. L., Warren, J. M., Woodruff, D. R., Bible, K., and Shaw, D. C.: Dynamics of water transport and storage in conifers studied with deuterium and heat tracing techniques, Plant Cell Environ., 29, 105-114, https://doi.org/10.1111/j.1365-3040.2005.01404.x, 2006.

Millar, C., Pratt, D., Schneider, D. J., and McDonnell, J. J.: A comparison of extraction systems for plant water stable isotope analysis, Rapid Commun. Mass Sp., 32, 1031-1044, https://doi.org/10.1002/rcm.8136, 2018.

Newman, B., Tanweer, A., and Kurttas, T.: IAEA Standard Operating Procedure for the Liquid-Water Stable Isotope Analyser, available at: http://www-naweb.iaea.org/napc/ih/documents/ other/laser_procedure_rev12.PDF (last access: 16 August 2021), 2009.

Oerter, E. J., Perelet, A., Pardyjak, E., and Bowen, G.: Membrane inlet laser spectroscopy to measure $\mathrm{H}$ and $\mathrm{O}$ stable isotope compositions of soil and sediment pore water with high sample throughput, Rapid Commun. Mass Sp., 31, 75-84, https://doi.org/10.1002/rcm.7768, 2016.

Orlowski, N., Frede, H.-G., Brüggemann, N., and Breuer, L.: Validation and application of a cryogenic vacuum extraction system for soil and plant water extraction for isotope analysis, J. Sens. Sens. Syst., 2, 179-193, https://doi.org/10.5194/jsss-2-179-2013, 2013.

Orlowski, N., Breuer, L., and McDonnell, J. J.: Critical issues with cryogenic extraction of soil water for stable isotope analysis, Ecohydrology, 9, 1-5, https://doi.org/10.1002/eco.1722, 2016a.

Orlowski, N., Pratt, D. L., and McDonnell, J. J.: Intercomparison of soil pore water extraction methods for 
stable isotope analysis, Hydrol. Process., 30, 3434-3449, https://doi.org/10.1002/hyp.10870, 2016 b.

Orlowski, N., Winkler, A., McDonnell, J. J., and Breuer, L.: A simple greenhouse experiment to explore the effect of cryogenic water extraction for tracing plant source water, Ecohydrology, 11, e1967, https://doi.org/10.1002/eco.1967, 2018a.

Orlowski, N., Breuer, L., Angeli, N., Boeckx, P., Brumbt, C., Cook, C. S., Dubbert, M., Dyckmans, J., Gallagher, B., Gralher, B., Herbstritt, B., Hervé-Fernández, P., Hissler, C., Koeniger, P., Legout, A., Macdonald, C. J., Oyarzún, C., Redelstein, R., Seidler, C., Siegwolf, R., Stumpp, C., Thomsen, S., Weiler, M., Werner, C., and McDonnell, J. J.: Inter-laboratory comparison of cryogenic water extraction systems for stable isotope analysis of soil water, Hydrol. Earth Syst. Sci., 22, 3619-3637, https://doi.org/10.5194/hess-22-3619-2018, 2018 b.

Orlowski, N., Pratt, D. L., and McDonnell, J. J.: Intercomparison of soil pore water extraction methods for stable isotope analysis and interpretation of hillslope runoff sources, Hydrol. Process., 33, 2939-2954, https://doi.org/10.1002/hyp.13539, 2019.

Penna, D., Hopp, L., Scandellari, F., Allen, S. T., Benettin, P., Beyer, M., Geris, J., Klaus, J., Marshall, J. D., Schwendenmann, L., Volkmann, T. H. M., von Freyberg, J., Amin, A., Ceperley, N., Engel, M., Frentress, J., Giambastiani, Y., McDonnell, J. J., Zuecco, G., Llorens, P., Siegwolf, R. T. W., Dawson, T. E., and Kirchner, J. W.: Ideas and perspectives: Tracing terrestrial ecosystem water fluxes using hydrogen and oxygen stable isotopes - challenges and opportunities from an interdisciplinary perspective, Biogeosciences, 15, 6399-6415, https://doi.org/10.5194/bg-15-6399-2018, 2018.

Pfautsch, S., Bleby, T. M., Rennenberg, H., and Adams, M. A.: Sap flow measurements reveal influence of temperature and stand structure on water use of Eucalyptus regnans forests, Forest Ecol. Manag., 259, 1190-1199, https://doi.org/10.1016/j.foreco.2010.01.006, 2010.

Pfautsch, S., Renard, J., Tjoelker, M. G., and Salih, A.: Phloem as Capacitor: Radial Transfer of Water into Xylem of Tree Stems Occurs via Symplastic Transport in Ray Parenchyma, Plant Physiol., 167, 963-971, https://doi.org/10.1104/pp.114.254581, 2015.

Poca, M., Coomans, O., Urcelay, C., Zeballos, S. R., Bodé, S., and Boeckx, P.: Isotope fractionation during root water uptake by Acacia caven is enhanced by arbuscular mycorrhizas, Plant Soil, 441, 485-497, https://doi.org/10.1007/s11104-019-04139$1,2019$.

Rothfuss, Y. and Javaux, M.: Reviews and syntheses: Isotopic approaches to quantify root water uptake: a review and comparison of methods, Biogeosciences, 14, 2199-2224, https://doi.org/10.5194/bg-14-2199-2017, 2017.

Rothfuss, Y., Vereecken, H., and Brüggemann, N.: Monitoring water stable isotopic composition in soils using gas-permeable tubing and infrared laser absorption spectroscopy, Water Resour. Res., 49, 3747-3755, https://doi.org/10.1002/wrcr.20311, 2013.

Saurer, M., Kirdyanov, A. V., Prokushkin, A. S., Rinne, K. T., and Siegwolf, R. T. W.: The impact of an inverse climateisotope relationship in soil water on the oxygen-isotope composition of Larix gmelinii in Siberia, New Phytol., 209, 955-964, https://doi.org/10.1111/nph.13759, 2016.

Schepper, V. De, van Dusschoten, D., Copini, P., Jahnke, S., and Steppe, K.: MRI links stem water content to stem diameter variations in transpiring trees, J. Exp. Bot., 63, 2645-2653, https://doi.org/10.1093/jxb/err445, 2012.

Schmitt, U. and Liese, W.: Response of xylem parenchyma by suberization in some hardwoods after mechanical injury, Trees, 8, 23-30, https://doi.org/10.1007/BF00240978, 1993.

Schwendenmann, L., Dierick, D., Kohler, M., and Holscher, D.: Can deuterium tracing be used for reliably estimating water use of tropical trees and bamboo?, Tree Physiol., 30, 886-900, https://doi.org/10.1093/treephys/tpq045, 2010.

Seeger, S. and Weiler, M.: Temporal dynamics of tree xylem water isotopes: In-situ monitoring and modelling, Biogeosciences Discuss. [preprint], https://doi.org/10.5194/bg-2021-35, in review, 2021.

Seeger, S., Rinderer, M., and Weiler, M.: Inferring plant physiologic parameters for root water uptake modelling from high frequency in-situ isotope measurements, EGU Gen. Assem. 2020, Online, 4-8 May 2020, EGU2020-22007, https://doi.org/10.5194/egusphere-egu2020-22007, 2020.

Sprenger, M., Herbstritt, B., and Weiler, M.: Established methods and new opportunities for pore water stable isotope analysis, Hydrol. Process., 29, 5174-5192, https://doi.org/10.1002/hyp.10643, 2015a.

Sprenger, M., Volkmann, T. H. M., Blume, T., and Weiler, M.: Estimating flow and transport parameters in the unsaturated zone with pore water stable isotopes, Hydrol. Earth Syst. Sci., 19 2617-2635, https://doi.org/10.5194/hess-19-2617-2015, 2015 b.

Sprenger, M., Leistert, H., Gimbel, K., and Weiler, M.: Illuminating hydrological processes at the soil-vegetation-atmosphere interface with water stable isotopes, Rev. Geophys., 54, 674-704, https://doi.org/10.1002/2015rg000515, 2016a.

Sprenger, M., Seeger, S., Blume, T., and Weiler, M.: Travel times in the vadose zone: Variability in space and time, Water Resour. Res., 52, 5727-5754, https://doi.org/10.1002/2015wr018077, $2016 b$.

Sprenger, M., Tetzlaff, D., Buttle, J., Laudon, H., Leistert, H., Mitchell, C. P. J., Snelgrove, J., Weiler, M., and Soulsby, C.: Measuring and Modeling Stable Isotopes of Mobile and Bulk Soil Water, Vadose Zone J., 17, 170149, https://doi.org/10.2136/vzj2017.08.0149, 2018

Sprenger, M., Llorens, P., Cayuela, C., Gallart, F., and Latron, J.: Mechanisms of consistently disjunct soil water pools over (pore) space and time, Hydrol. Earth Syst. Sci., 23, 2751-2762, https://doi.org/10.5194/hess-23-2751-2019, 2019.

Stumpp, C. and Hendry, M. J.: Spatial and temporal dynamics of water flow and solute transport in a heterogeneous glacial till: The application of high-resolution profiles of $\delta^{18} \mathrm{O}$ and $\delta^{2} \mathrm{H}$ in pore waters, J. Hydrol., 438-439, 203-214, https://doi.org/10.1016/j.jhydrol.2012.03.024, 2012.

Vargas, A. I., Schaffer, B., Yuhong, L., and da Silveira Lobo Sternberg, L.: Testing plant use of mobile vs. immobile soil water sources using stable isotope experiments, New Phytol., 215, 582 594, https://doi.org/10.1111/nph.14616, 2017.

Volkmann, T. H. M. and Weiler, M.: Continual in situ monitoring of pore water stable isotopes in the subsurface, Hydrol. Earth Syst. Sci., 18, 1819-1833, https://doi.org/10.5194/hess-18-1819-2014, 2014.

Volkmann, T. H. M., Kühnhammer, K., Herbstritt, B., Gessler, A., and Weiler, M.: A method for in situ monitoring of the isotope composition of tree xylem water using 
laser spectroscopy, Plant Cell Environ., 39, 2055-2063, https://doi.org/10.1111/pce.12725, 2016a.

Volkmann, T. H. M., Haberer, K., Gessler, A., and Weiler, M.: Highresolution isotope measurements resolve rapid ecohydrological dynamics at the soil-plant interface, New Phytol., 210, 839-849, https://doi.org/10.1111/nph.13868, 2016b.

von Freyberg, J., Allen, S. T., Grossiord, C., and Dawson, T. E.: Plant and root-zone water isotopes are difficult to measure, explain, and predict: Some practical recommendations for determining plant water sources, Meth. Ecol. Evol., 11, 1352-1367, https://doi.org/10.1111/2041-210X.13461, 2020.

Walker, G. R., Woods, P. H., and Allison, G. B.: Interlaboratory comparison of methods to determine the stable isotope composition of soil water, Chem. Geol., 111, 297-306, https://doi.org/10.1016/0009-2541(94)90096-5, 1994.
Wassenaar, L. I., Hendry, M. J., Chostner, V. L., and Lis, G. P.: High Resolution Pore Water $\delta^{2} \mathrm{H}$ and $\delta^{18} \mathrm{O}$ Measurements by $\mathrm{H}_{2} \mathrm{O}_{\text {(liquid) }}-\mathrm{H}_{2} \mathrm{O}_{\text {(vapor) }}$ Equilibration Laser Spectroscopy, Environ. Sci. Technol., 42, 9262-9267, https://doi.org/10.1021/es802065s, 2008.

Zhao, L., Wang, L., Cernusak, L. A., Liu, X., Xiao, H., Zhou, M., and Zhang, S.: Significant Difference in Hydrogen Isotope Composition Between Xylem and Tissue Water in Populus Euphratica, Plant Cell Environ., 39, 1848-1857, https://doi.org/10.1111/pce.12753, 2016. 